\title{
Are intact peptides absorbed from the healthy gut in the adult human?
}

\author{
Warren M. Miner-Williams ${ }^{1}$, Bruce R. Stevens ${ }^{2}$ and Paul J. Moughan ${ }^{1 *}$ \\ ${ }^{1}$ Riddet Institute, Massey University, Private Bag 11-222, Palmerston North, New Zealand \\ ${ }^{2}$ College of Medicine, Department of Physiology and Functional Genomics, University of Florida, Gainesville, FL, USA
}

\begin{abstract}
For over 100 years it was believed that dietary protein must be completely hydrolysed before its constituent amino acids could be absorbed via specific amino acid transport systems. It is now known that the uptake of di- and tripeptides into the enterocyte is considerable, being transported across the intestinal endothelium by the PepT1 $\mathrm{H}^{+}$/peptide co-transporter. There is also evidence that some di- and tripeptides may survive cytosolic hydrolysis and be transported intact across the basolateral membrane. However, other than antigen sampling, the transport of larger intact macromolecules across the intestinal endothelium of the healthy adult human remains a controversial issue as there is little unequivocal in vivo evidence to support this postulation. The aim of the present review was to critically evaluate the scientific evidence that peptides/proteins are absorbed by healthy intestinal epithelia and pass intact into the hepatic portal system. The question of the absorption of oliogopeptides is paramount to the emerging science of food-derived bioactive peptides, their mode of action and physiological effects. Overall, we conclude that there is little unequivocal evidence that dietary bioactive peptides, other than diand tripeptides, can cross the gut wall intact and enter the hepatic portal system in physiologically relevant concentrations.
\end{abstract}

Key words: Bioactive peptides: Absorption: Gastrointestinal tract: Opioids: PepT1 $\mathbf{H}^{+} /$peptide co-transporter: Lactotripeptides

\section{Introduction}

A primary function of the gastrointestinal tract (GIT) is to digest dietary macromolecules and absorb the resultant nutrients from the complex environment of the gut lumen into the hepatic portal system. Yet accruing evidence now indicates that certain intact peptides escape hydrolysis and may exert physiological and immunological effects directly within the gut wall or systemically after being absorbed intact into the portal blood.

The intestinal lumen is a noxious environment and the intestinal epithelia form a selective barrier between the cells of the underlying lamina propria and the external environment ${ }^{(1,2)}$. The toxic milieu of the intestinal lumen includes food antigens, anti-nutritional factors and potentially damaging secretions (which include bile salts, acids and digestive enzymes), food toxins and pathogenic bacteria $^{(2,3)}$. The GIT is also an integral part of the body's immune system and the majority of the body's immune cells are located in the $\operatorname{GIT}^{(3,4)}$. Maintaining the integrity of the mucosal barrier is paramount for gut homeostasis and immunological defence, as breaches of this system have been implicated in a number of inflammatory diseases ${ }^{(5)}$.
The digestion and nutrient assimilation of ingested protein by the GIT have, according to Matthews ${ }^{(6)}$, been the subject of speculation and debate since the late 18th century. At the beginning of the 20th century, the discovery of the protease-containing 'erepsin' by the German physiologist Otto Cohnheim ${ }^{(7)}$ and the demonstration that amino acids are the products of protein digestion in the small intestine ${ }^{(8,9)}$ led scientists to believe that proteins must be fully hydrolysed before their constituent amino acids are absorbed. We now know that the digestion of proteins is primarily undertaken by both gastric and pancreatic proteases, with the resulting large peptides being hydrolysed further by peptidases present on the enterocytic brush border. Free amino acids are then absorbed by the enterocytes via specific amino acid transport systems ${ }^{(10)}$, for example, the $\mathrm{B}^{0}$ system, a $\mathrm{Na}^{+}-$ dependent and $\mathrm{Cl}^{-}$-independent transporter that is responsible for the uptake of most neutral amino acids at the brush-border membranes (BBM) of the enterocytes.

The doctrine that proteins must be completely hydrolysed before the absorption of their component amino acids prevailed until Newey \& Smyth ${ }^{(11)}$ provided the first convincing evidence that dipeptides could be

Abbreviations: ACE, angiotensin-converting enzyme; AngI, angiotensin I; AngII, angiotensin II; BBM, brush-border membrane; GIT, gastrointestinal tract; HRP, horseradish peroxidase; IPP, isoleucine-proline-proline; RAS, renin-angiotensin system; SHR, spontaneously hypertensive rat; VPP, valine-prolineproline; VY, valine-tyrosine.

* Corresponding author: Professor P. J. Moughan, email p.j.moughan@massey.ac.nz 
absorbed. Subsequently, further studies suggested the existence of a transport system for the absorption of diand tripeptides ${ }^{(12,13)}$, which Ganapathy \& Leibach described in $1983^{(14)}$. First cloned by Fei et al. ${ }^{(15)}$, this intestinal transport system is a transmembrane protein known as the PepT1 $\mathrm{H}^{+}$/peptide co-transporter (also known as solute carrier family 15 member 1; SLC15A1) which in humans is encoded by the SLC15A1 gene ${ }^{(16)}$. By the late 1960s and early 1970s researchers had established that substrates for transport across the gut wall are limited to di- and tripeptides ${ }^{(17-19)}$; neither free amino acids nor peptides containing four or more amino acids are accepted as substrates by the PepT1 transporter ${ }^{(20-22)}$. In contrast to other transporters the PepT1 has an enormous range of substrate specificity ${ }^{(21)}$ which Adibi $^{(23)}$ suggests includes some 400 dipeptides and 8000 tripeptides. Peptides consisting of L-amino acids are preferred over those containing individual $\mathrm{D}$-amino acid residues, while those consisting solely of D-stereoisomers are not transported ${ }^{(24,25)}$. PepT1 (Fig. 1) ${ }^{(16,26,27)}$ is a bidirectional transporter where the direction and rate of absorption are dependent upon the membrane potential plus proton gradient. However, the binding affinity of substrates on

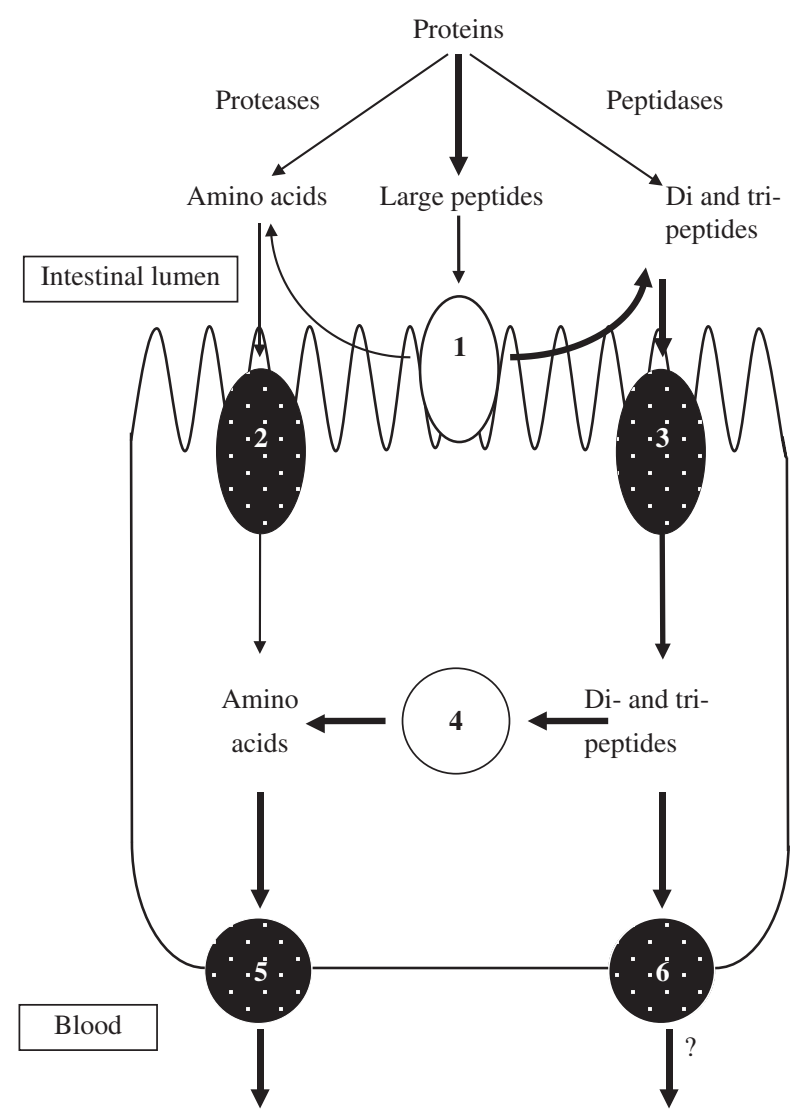

Fig. 1. Digestion and absorption of protein by the mammalian small-intestinal enterocyte (from Brandsch \& Brandsch ${ }^{(16)}$; reproduced with the permission of Wageningen Academic Publishers). At the apical membrane: 1, peptidases; 2, amino acid transport systems, such as the $B^{0}$ system; 3 , peptide transporter; 4 , cytosolic peptidases. At the basolateral membrane: 5 , amino acid transport systems; 6 , unknown peptide transport system. the luminal side is $5-100 \%$ higher than on the intracellular side of the apical membrane ${ }^{(21)}$. Interestingly the rate of amino acid absorption via the PepT1 system is believed to be $70-80 \%$ greater than the luminal absorption of similar free amino acids ${ }^{(28)}$, a mechanism that may be attributed to the transporter's high capacity ${ }^{(29)}$ and/or its high expression in the small intestine ${ }^{(21)}$.

Although the absorption of di- and tripeptides across the apical membrane in humans has been proven, little is known of the existence of a separate basolateral peptide transporter ${ }^{(16,21)}$. The majority of di- and tripeptides that enter the enterocytes may not leave the cell intact, due to the presence of cytosolic peptidases that release amino acids for intracellular metabolism or efflux into the portal circulation, via amino acid transporters located on the basolateral membrane ${ }^{(23)}$. The efflux of hydrolysis-resistant di- and tripeptides across the basolateral membrane and into the hepatic portal system seems to be low ${ }^{(16,21,30-32)}$. Both di- and tripeptides resistant to cytosolic hydrolysis may also be broken down by vascular endothelial tissue peptidases and soluble plasma peptidases ${ }^{(33-35)}$; indeed, the half-life of many peptides in the plasma is very short ${ }^{(20,36,37)}$.

It has long been established that the mammalian neonatal small intestine is permeable to $\gamma$-globulins from maternal colostrum as a mechanism of passive immunisation $^{(38)}$ and that this protects the neonate during the development of immunological competence and such permeability diminishes with maturation ${ }^{(39)}$. However, the adult's intestinal epithelium is not fully impermeable to all macromolecules; in the healthy mature gut small amounts of food-derived antigens and micro-organisms may be absorbed and induce a homeostatic immune response dominated by immune intolerance to dietary antigens ${ }^{(40-42)}$. The permeation of intact proteins is protein specific and tightly regulated ${ }^{(16)}$. Excessive absorption of antigenic proteins can induce local or systemic pathogenesis ${ }^{(43,44)}$, for example, inflammatory bowel disease $\mathrm{e}^{(45,46)}$, coeliac disease ${ }^{(47,48)}$ and other food allergies $^{(49)}$. In mature mammals the intestinal epithelium can absorb small quantities of protein by endocytosis; however, such absorption may be several orders of magnitude smaller than $0 \cdot 1 \%$ of an administered dose ${ }^{(16)}$. Such small quantities fall within the scope of antigen sampling.

Enmeshed in the debate of whether peptides, large or small, can be absorbed intact by the healthy GIT is the notion of food-derived bioactive peptides, their absorption from the small intestine and their physiological effects. Traditionally the principal consideration in the evaluation of dietary protein quality has been its nutritional value and the availability of $\mathrm{N}$ from constituent amino acids. However, more recently there has been the discovery that specific protein fragments have physiological effects and influence body health ${ }^{(50-53)}$. As a result the physiological activity of peptides ('bioactive peptides') released from exogenous dietary precursor proteins during digestive 
enzymic proteolysis has been of interest to researchers since their discovery in the $1970 \mathrm{~s}^{(54)}$. Both the reported physiological effects of bioactive peptides and the foods in which they have been found are numerous ${ }^{(55-57)}$.

\section{Pathways for the absorption of macromolecules from the} gastrointestinal tract

The epithelium of the small intestine is lined with a layer of absorptive cells joined at their apical poles by junctional complexes that prevent the ingress of macromolecules. In addition, the apical surface is coated with mucus composed of hydrolysis-resistant peptidoglycans holding IgA, which impedes the absorption of luminal antigens ${ }^{(58)}$. Nevertheless, a small quantity of hydrolysis-resistant antigenic material, macromolecules and indeed whole microbial cells may be absorbed by the mucosal tissues via transport systems that predominantly involve the adaptive and innate immune responses of the gut ${ }^{(59,60)}$. The possible pathways for the absorption of peptides from the intestinal lumen (illustrated in Fig. 2) include: (a) paracellular pathways, via the tight junctions; (b) passive diffusion through the enterocytes; (c) endocytosis; and (d) carrier-mediated transport systems, for example, PepT1.

The paracellular pathway involves structures that join adjacent intestinal epithelial cells and are delineated by tight junctions, adherens junctions and desmosomes ${ }^{(40)}$. The rate-limiting factor in the paracellular diffusion of molecules involves the tight junctions, a network of transmembrane proteins (claudins ${ }^{(61)}$, occludin ${ }^{(62)}$ and junctional adhesion molecule $\mathrm{A}^{(63)}$ and tricellulin ${ }^{(64)}$ ) that control the tight junction's plasticity and permeability. Tight junctions form pores that range in diameter between $0.4-0.9 \mathrm{~nm}$ in the villi to $5-6 \mathrm{~nm}$ in the crypts. Tight junctions allow the diffusion of mostly cations and inert small molecules $(<600 \mathrm{Da})$ such as water-soluble peptides ${ }^{(20)}$.
The human gut has an estimated surface area of $200 \mathrm{~m}^{2(65)}$ and the area available to paracellular diffusion is estimated to be $0.01 \%$ of this ${ }^{(66)}$. However, in the healthy human gut, paracellular diffusion of antigens through the tight junctions is very low ${ }^{(58)}$ and remains even in areas of desquamation ${ }^{(67)}$.

Highly lipid-soluble peptides may enter the enterocytes by passive diffusion where they are susceptible to hydrolytic degradation by cytosolic enzymes ${ }^{(20)}$. Because large polar molecules such as peptide fragments $>600 \mathrm{Da}$ cannot pass through the hydrophobic enterocyte cell membrane they may be captured by invagination of the apical membrane into vesicles that normally fuse with lysosomes to form phagolysosomes. The principal function of the phagolysosomes is the enzymic digestion of the macromolecules they contain. Only protein that escapes hydrolysis within these structures can be drawn across the enterocytes to be secreted at the basolateral membrane. The transcytosis of internalised vesicles may carry specifically bound ligands (receptor-mediated transcytosis), non-specifically adsorbed ligands (adsorptive transcytosis) or fluids (fluidphase transcytosis) from the apical membrane across the cell to the basolateral membrane ${ }^{(68,69)}$. Partially degraded food antigens in early endosomes bind to major histocompatibility complex (MHC) class II molecules in an intracellular endocytotic compartment. Inward invagination of the MHC II compartment leads to the formation of exosomes, small membrane vesicles (40-90 nm) bearing MHC class II/peptide complexes at their surface ${ }^{(40)}$. Antigen-loaded exosomes can then fuse with the basement membrane before being released into the extracellular medium to interact with local immune cells ${ }^{(70)}$. Antigen sampling is thought to explain the presence of ferritin, detected using electron microscopy $(650 \mathrm{kDa}$ with a size of 5-6 nm) in membrane-bound vesicles within the intestinal epithelial cells of the hamster following its intraluminal infusion ${ }^{(71)}$.
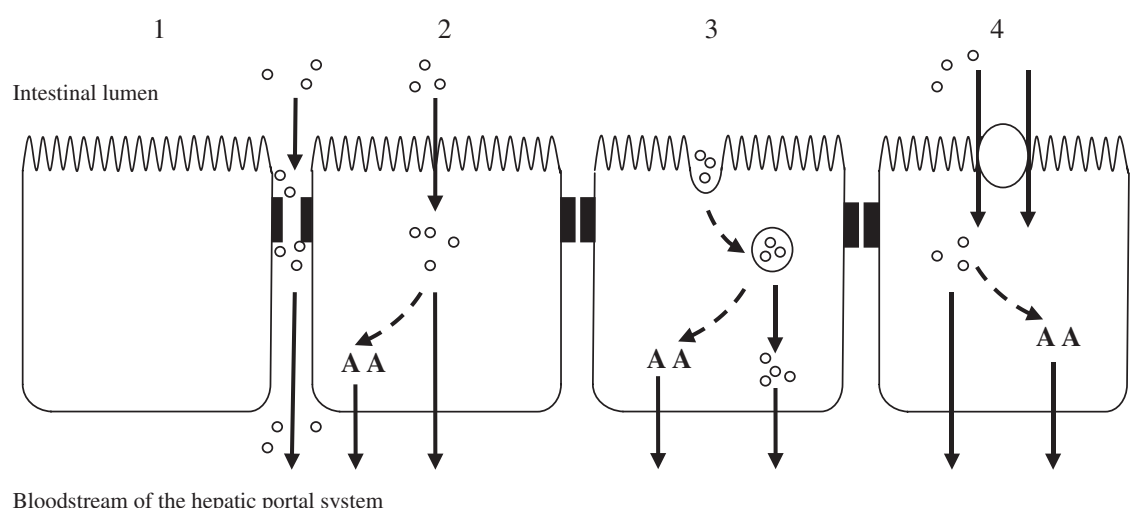

Bloodstream of the hepatic portal system

Fig. 2. Potential mechanisms of small-intestinal epithelium movement of peptides: 1, paracellular - increased permeability of tight junctions may permit the passage of peptides; 2, passive diffusion - cell-penetrating peptides are capable of transporting peptides as cargo; 3 , endocytosis, followed by the endosomal release of the peptides; 4 , carrier-mediated transport - transport via the intestinal $\mathrm{H}^{+} / \mathrm{di}$ - and tripeptide transporter PEPT1. Inside the enterocyte peptides can be hydrolysed into their constituent amino acids (AA) before being transported across the basolateral membrane by specific AA transporters. It is thought, although not proven, that the transport of peptides across the basolateral membrane is mediated through other transporters such as those suggested by Terada et al. ${ }^{(310,311)}$, Shepherd et al. ${ }^{(312)}$ and Irie et al. ${ }^{(313)}$. 
Another important antigen-sampling pathway for accessing specific proteins/antigens and bacterial cells involves the phagocytotic activity of follicle-associated epithelial cells (M-cells) located in Peyer's patches. In a similar fashion, inert particulate materials have also been shown to be absorbed from the intestinal lumen. Gustave Herbst in 1843 observed starch grains in the blood of dogs $3 \mathrm{~h}$ after feeding them a starch suspension, observations that were confirmed by a series of experiments in animals and human subjects by Volkheimer in $1964^{(72)}$. Weiner suggests that most absorbed particles are sequestered in macrophages within the Peyer's patches; nonsequestered particles are thought to be transported via the lymph rather than the portal blood ${ }^{(73)}$.

However, the absorption of intact macromolecules from the healthy adult human intestine remains a controversial issue as there is little unequivocal in vivo evidence (other than antigen sampling) in the literature demonstrating this phenomenon. The aim of the present review was to critically evaluate the evidence in the scientific literature that larger peptides and proteins are absorbed, in quantities greater than that required for antigen sampling, by healthy adult human intestinal epithelia; and that such molecules can then pass intact into the hepatic portal system, whereby they may invoke a targeted physiological response from the host.

\section{Evidence for the absorption of peptides from the healthy} gut of adult humans

\section{Early claims for oligopeptide absorption}

A number of articles commonly cited as being evidential of oligopeptide absorption arose before the discovery of the PepT1 $\mathrm{H}^{+}$/peptide co-transporter. Agar et al. ${ }^{(74)}$ demonstrated unequivocally the transmural transport of unhydrolysed dipeptides, such as glycyl-glycine, an observation soon confirmed by other researchers ${ }^{(11,75)}$. Hueckel \& Rogers ${ }^{(76)}$ reported an increase in bound hydroxyprolinecontaining dipeptides but not of free hydroxyproline in the urine of human subjects fed $30 \mathrm{~g}$ of gelatin, indicating that these peptides were absorbed intact before being excreted during the succeeding $5.5 \mathrm{~h}$. Interestingly when the same experiment was repeated with rats both bound and free hydroxyproline was present in the urine when the diet contained gelatin. However, in monkeys and dogs the quantities of free and bound urinary hydroxyproline were the same whether the animals ingested a normal diet or one containing gelatin. This discordant result demonstrates that the choice of a human analogue is critical in physiological research. Hellier et al. ${ }^{(77)}$ reported the intestinal absorption of two dipeptides, glycyl-glycine and glycyl-L-alanine, in human subjects and noted that the constituent amino acids were absorbed faster when presented as dipeptides rather than as free amino acids. However, a third dipeptide, glycyl-L-lysine, known to be transported intact from the intestinal lumen, was hydrolysed to its constituent amino acids before reaching the portal venous blood, emphasising that the fate of dipeptides is not always the same. Later, Boullin et al. ${ }^{(78)}$ reported the absorption of six different dipeptides in the rat. The intact dipeptides were subsequently detected by ionexchange chromatography in blood samples taken from the superior mesenteric vein.

The early work of Adibi ${ }^{(79)}$ and Silk et al. ${ }^{(80)}$ suggests that not all tripeptides in humans are hydrolysed within the lumen or at the BBM, and that some of the possible 8000 tripeptides produced during the digestion of dietary protein may be absorbed intact. Compelling evidence for the absorption of intact peptides by the gut in humans comes from individuals with genetic disorders involving amino acid transporters; these patients do not appear to suffer from protein malnourishment as the absorption of intact peptides is unaffected ${ }^{(81-84)}$. Whether tetrapeptides can be absorbed by the enterocytes of the human jejunum was studied by Adibi \& Morse ${ }^{(85)}$. They determined that tetraglycine was not absorbed by the enterocytes by the same mechanism as tri- or diglycine and although they did not discount the absorption of the tetrapeptide they could not detect any tetraglycine within the mucosal cells $^{(85)}$. They have suggested that tetraglycine is hydrolysed by mucosal-bound oligopeptidases and the uptake of homologous glycine oligopeptides by the human mucosal epithelium is restricted to diglycine and triglycine. In vivo studies in animals offer only conflicting evidence for the absorption of tetrapeptides. In the rat, Chung et $a l .{ }^{(86)}$ reported that L-leucyl-triglycine may be absorbed intact before being hydrolysed by cytoplasmic peptidases. On the other hand, a study by Burston et al. ${ }^{(87)}$ using rings of everted rat and hamster jejunum indicated that intact tetrapeptides were not absorbed but were hydrolysed to tri- and dipeptides by brush-border peptidases before uptake. The absorption of tetrapeptides by passive or facilitated diffusion has been reported by several researchers $^{(88-90)}$. Both Chung et al. ${ }^{(86)}$ and Rogers et al. ${ }^{(91)}$ reported that rat small intestine could actively absorb intact tetrapeptides ${ }^{(86,91)}$; however, Kerchner \& Geary ${ }^{(89)}$ were critical of Chung's experimental approach, citing extensive incubation times and the reuse of perfusion jejunum loops, with no correction for substrate entrapped in the extracellular space, insufficient evaluation of the cytoplasmic peptidase activity and the estimation of intact tetrapeptide uptake by an indirect method. They suggest that the unprotected peptides used were rapidly hydrolysed to their amino acid residues by brush-border and cytosol enzymes. With extensive incubation times in an ileum-everted sac preparation coupled with such a very high substrate concentration $(20 \mathrm{~mm})$ this investigation would have been unable to determine whether the passage of peptide was active or passive. Kerchner \& Geary ${ }^{(89)}$ suggest that neither of these studies conclusively 
demonstrates the presence of an active transport process for oligopeptides.

Evidence for the absorption of larger peptides has been reported for: the pentapeptide metkephamid in the rat ${ }^{(92)}$; the orally active cyclic octapeptide analogue of somatostatin, octreotide, in the rat ${ }^{(93)}$; the renin-inhibiting nonapeptide in the rabbit jejunum ${ }^{(94)}$; the nonapeptide vasopressin also in the rabbit ${ }^{(95)}$; and in vivo, the decapeptide luteinising hormone-releasing factor ${ }^{(96)}$. Another large peptide that is absorbed via passive diffusion into enterocytes in humans is the orally active immunosuppressive endecapeptide, cyclosporin $\mathrm{A}^{(97,98)}$. This large peptide is reported as having absolute bioavailabilities between $<5$ and $89 \%$. Using ultrastructural imaging, horseradish peroxidase (HRP; $40 \mathrm{kDa}$ ) has been shown to be absorbed across the intestinal wall of the rat via transcytotic vesicles $^{(99)}$. However, in Ussing chamber experiments the rate of membrane permeation across rabbit jejunum was found to be extremely low $\left(3 \mathrm{pmol} / \mathrm{h} \text { per } \mathrm{cm}^{2}\right)^{(100)}$. M-cells in the Peyer's patches of the ileum can transport macromolecules such as lectins or $\operatorname{IgA}^{(101,102)}$ although the concentration of proteins reaching the systemic circulation is considered to be very low ${ }^{(103)}$.

Hemmings et al. ${ }^{(104)}$ reported that the large molecular mass breakdown products of four iodinated proteins were absorbed into the circulation and tissues of orally fed adult rats. In this paper the molecular mass of the breakdown products was not given and the issue of whether the irradiated iodine remains with the protein or if it is transferred to protein synthesised de novo could not be assured. However, in a later study ${ }^{(105)}$ these questions were addressed. The molecular mass of the irradiated breakdown products ranged between 20 and $50 \mathrm{kDa}$ and their origin was confirmed immunologically using antisera specific to the original molecule. Using ${ }^{3} \mathrm{H}$-labelled bovine IgG the authors detected the presence of this large protein, or of fragments sufficient in size to retain the markers in adult ileal epithelial cells by direct deposition autoradiography at the electron microscopic level ${ }^{(106)}$. They suggest there may be a universal necessity for body cells to be permeable to proteins of many types and there is a constant traffic of protein molecules into all body cells. The method by which the human gut might absorb such large protein fragments is unclear although the transcytosis of IgG in the neonatal rat has been reported ${ }^{(107,108)}$ and an increased permeability of tight junctions may permit the passage of larger peptides. Bloch et al. ${ }^{(109)}$ demonstrated that ${ }^{125}$ I-labelled polypeptide fragments $(6-20 \mathrm{kDa})$ from a pepsin digestion of bovine serum albumin were transferred from the mucosal to the serosal surface of the enterocytes when infused into everted jejunual gut sacs of rats. In subsequent in vivo studies they found that nanogram amounts of unlabelled immunoreactive fragments were detected by RIA of mesenteric and portal venous blood following their infusion into the jejunum. However, they failed to detect such fragments in the systemic circulation and suggest that this must be due to their rapid clearance. Caution is required in the interpretation of these results owing to the direct infusion of the jejunum circumventing hydrolysis by gastric and intestinal peptidases, the small and nutritionally insignificant amounts of the polypeptides detected in the portal and mesenteric venous blood and the short halflife of such fragments in the systemic circulation. On balance it would appear that small quantities of di- and tripeptides are absorbed from the adult human digestive tract, but the evidence for the absorption of larger peptides in other than very small amounts is not strong.

\section{Food-derived bioactive peptides}

The discovery of peptides that may induce physiological effects in the host following the oral administration of certain proteins or foods has led to publications that review such compounds and their sources ${ }^{(110-112)}$. Agyei \& Danquah $^{(113,114)}$ predict that food-derived bioactive peptides are of such significance that they will, in the future, sustain a new industry.

Such bioactivity infers the absorption of peptides and in the eyes of many researchers the absorption of oligopeptides from the small intestine is a foregone conclusion $^{(110,111,115,116)}$. However, a critical examination of the literature reveals that such a hypothesis is difficult to substantiate. Whereas there is evidence for some uptake of intact di- and tripeptides from the human GIT, such uptake is not ubiquitous and there is little support for the uptake of tetrapeptides and larger peptides.

\section{The lactotripeptides isoleucine-proline-proline and valine-proline-proline}

Some of the most extensively studied food-derived bioactive peptides are those with potential antihypertensive properties and in particular those that may inhibit the angiotensin-converting enzymes (ACE) ${ }^{(117)}$. Séverin \& $\mathrm{Xia}^{(118)}$ reported that two lactotripeptides (valine-prolineproline (VPP) and isoleucine-proline-proline (IPP)) from milk were able to cross the intestinal barrier and, postabsorption, inhibit the production of angiotensin II (AngII) in the bloodstream. They caution that not all bioactive peptides may be so absorbed:

...in order to function physiologically in the human body, the active peptides must be absorbed from the intestine in an active form. Di- and tripeptides can be easily absorbed in the intestine; however, it is not clear that larger bioactive peptides containing in excess of three amino acids are absorbed from the intestine and reach the target organ. Most of the claimed physiological properties of the casein-based bioactive peptides have been carried out in vitro or in animal model systems and these hypothesized properties remain to be proven in humans.

The key point of this cautionary note is that bioactive peptides must be absorbed in an active form, 
a point central to the debate as to whether orally ingested foods can exert physiological changes systemically postabsorption or not.

The research of Nakamura et al. ${ }^{(119)}$ is often quoted as demonstrating that ingestion of 'Calpis', a Japanese sour milk, or a preparation of the pure tripeptides (VPP and IPP), decreased the systolic blood pressure in spontaneously hypertensive rats (SHR), 6-8 h after oral administration ${ }^{(20,35,57,116,118,120-126)}$. However, Nakamura et $a .^{(119)}$ and others ${ }^{(122,127)}$ also showed that the Calpis sour milk and mixed tripeptides did not change the systolic blood pressure of the normotensive strain of Wistar-Kyoto rats, important data that many of the researchers citing this paper have not mentioned ${ }^{(35,57,116,118,126)}$. Interestingly, at the conclusion of their 2009 study, Nakamura et al. (128) $^{\text {(128) }}$ state that it has been determined consistently that in Japanese populations the blood pressure response to the lactotripeptides is much greater than that in other populations, although it is unclear why this is so. It should be emphasised that unlike in their earlier 1995 study ${ }^{(119)}$ using rats, in this study of human subjects Nakamura et $a l .{ }^{(128)}$ did not use normotensive subjects or a placebo control with which to compare their data.

Nakamura et al. ${ }^{(128)}$ and others have reported that the two lactotripeptides VPP and IPP have been shown to have significant blood pressure-lowering activity $(119,123,129-134)$. They consider that both VPP and IPP are absorbed into the bloodstream and into the cells of the aorta after oral administration and inhibit ACE activity in vascular endothelial cells ${ }^{(128,135)}$. The 2009 study by Nakamura et al. of human subjects was small ( $n$ 12) and not placebo-controlled. In their earlier study, Nakamura and colleagues $^{(135)}$ suggested that the two lactotripeptides could be transported intact through the intestinal wall via paracellular routes. However, the molecular mass of the lactotripeptides is over $300 \mathrm{Da}$ and, as Lennernäs ${ }^{(66)}$ conjectures, compounds with a molecular mass greater than $200 \mathrm{Da}$ are too large for the intercellular space between the enterocytes and that absorption via paracellular transport is unlikely. The latter hypothesis was corroborated by observations that small hydrophilic molecules (for example, creatinine $113 \mathrm{Da}$ ) were affected by solvent drag and transported via the paracellular route, whereas larger hydrophilic molecules such as D-glucose (180 Da) and L-DOPA (L-3,4-dihydroxyphenylalanine) (197 Da) were not $^{(136-138)}$.

In an in vitro study using monolayer-cultured human intestinal Caco-2 cells, Satake et al ${ }^{(139)}$ also suggested that lactotripeptides were transported across the cells via the paracellular route. They suggest that because the passage of VPP across the Caco-2 cell monolayers was only weakly inhibited by the addition of a competitive substrate, that the PepT1 peptide transporter was not the major pathway. They also reported that no intact VPP was detected in the Caco-2 cells, suggesting that any peptides entering the cells were rapidly hydrolysed by cytosolic peptidases. As the lactotripeptides are only weakly hydrophobic, absorptive transcytosis could also be discounted as a major transport mechanism ${ }^{(140)}$. Likewise, Camenisch et al. ${ }^{(140)}$ predicted that lactotripeptides would not be expected to penetrate Caco-2 cells via transcellular passive diffusion. With little or no evidence that lactotripeptides are absorbed via the PepT1 transporter suggests that this pathway may not be open to all di- and tripeptides. Therefore the belief that the transporter can essentially transport all di- and tripeptides ${ }^{(21,23,24,141)}$ may require amendment. To this end, Brandsch et al. ${ }^{(142)}$ have reported that the PepT1 transporter can accept most but not all proteinogenic di- and tripeptides as substrates.

Mizuno et al. ${ }^{(123)}$, experimenting with human volunteers, administered the two peptides orally, in tablet form, at four different dose rates. They found that the reduction in systolic blood pressure was dose-dependent and most effective in mildly hypertensive subjects. However, they also found that there was no statistically significant reduction in diastolic blood pressure among their test groups or in comparison with the control group who received a placebo. If such an antihypertensive effect can be sustained, then it may be mediated through receptors on the intestinal wall ${ }^{(57,143)}$.

A study in the pig by van der Pijl et al. ${ }^{(144)}$ highlighted that efficacy studies usually present end-point measurements (for example, blood pressure), but hardly ever report plasma concentrations of the bioactive peptides involved. They found no data in the literature pertaining to the absolute bioavailability or other pharmacokinetic/ pharmacodynamic properties of the lactotripeptides. With respect to the pharmacokinetics of three proline-rich tripeptides (VPP, IPP and leucine-proline-proline) van der Pijl et al. ${ }^{(144)}$ went to extraordinary lengths to determine the very low concentration of these intact peptides in the bloodstream following intragastric infusion. Using liquid chromatography/MS they found the absolute bioavailability of the three peptides to be approximately $0.1 \%$. In one experiment the half-lives of absorption and elimination for VPP and IPP following intragastric dosing (4 mg of each lactotripeptide per $\mathrm{kg}$ body weight dissolved in $40 \mathrm{ml}$ of iso-osmolar saline) were determined by van der Pijl et al. ${ }^{(144)}$ to be $12 \pm 6$ and $9 \pm 1 \mathrm{~min}$, respectively. This suggested that the low absorption of these peptides was due to peptidase activity in the lumen, BBM and cytosol. With the effective plasma concentration for the inhibition of ACE being estimated by van Platerink et $a l^{(145)}$ to be $5.6 \mu \mathrm{mol}$, the plasma concentrations determined by van der Pijl et al. ${ }^{(144)}$ were approximately 1000-fold less and far below the effective concentration required to have any influence on lowering blood pressure. The pharmacokinetic properties of the tripeptides tested make it unlikely that physiological effects, such as a reduction in blood pressure, are the result of prolonged high plasma peptide concentrations.

In human subjects, following an oral dose of lactotripeptide in enriched yoghurt (250 $\mathrm{ml}$ containing approximately 
$20 \mathrm{mg}$ of both IPP and VPP), Foltz et al. ${ }^{(125)}$ determined the maximal plasma concentration of IPP to be less than $1 \mathrm{pmol} / \mathrm{ml}$ and concluded this to be far below its effective concentration for ACE inhibition determined in vitro. The required plasma concentration of the lactotripeptides known to exert ACE inhibition are approximately 1000fold higher than reported plasma concentrations in animal or human trials ${ }^{(125)}$.

Despite these results demonstrating a low bioavailability for the peptides leading to plasma concentrations below the effective concentration for ACE inhibition ${ }^{(125,144)}$, many researchers continue to report that lactotripeptides are absorbed in physiologically meaningful amounts (for reviews, see Korhonen ${ }^{(146)}$ and Ricci et al. $\left.{ }^{(147)}\right)$.

Both Fitzgerald et al. ${ }^{(148)}$ and Foltz et al. ${ }^{(125)}$ report that previously studied ACE-inhibitory bioactive peptides failed to lower blood pressure in in vivo studies, highlighting the intestinal breakdown of the so-called stable proline-rich tripeptides ${ }^{(20,149)}$. Only a few of the great number of the milk peptides that have been identified as having antihypertensive properties in in vitro experiments have so far been proven to be clinically effective in vivo, in either animal or human studies ${ }^{(20,148,150-152)}$.

Having studied the lactotripeptides in detail ${ }^{(117,125,144)}$, Foltz et al. ${ }^{(30,125)}$ and van der Pijl et al. ${ }^{(144)}$ stated that although these peptides possess high proteolytic stability their bioavailability in pigs is less than $0.1 \%$, with a very low elimination half-life. In humans the maximal plasma concentration was no greater than high picomolar concentrations ${ }^{(30)}$. Foltz et al. ${ }^{(30)}$ argue that there is no scientific evidence that any other dietary peptides have better absorption than the lactotripeptides or plasma clearance profiles that could result in acceptable bioavailability or transiently high, free plasma concentrations.

A very low bioavailability for the dipeptide valinetyrosine (VY), extracted from sardine muscle, was observed in a study by Matsui et al. ${ }^{(153)}$. From a maximal oral dose of $12 \mathrm{mg}$ dissolved in $100 \mathrm{ml}$ of water the highest plasma concentration of VY was determined to be 1.9 $\mathrm{pmol} / \mathrm{ml}$ (equivalent to $532 \mathrm{pg} / \mathrm{ml}$ ), $2 \mathrm{~h}$ after its administration. Although the plasma peptide concentration increased post-ingestion it did so in a non-linear dosedependent manner. The maximum plasma concentration was determined to be $1 / 300$ of the $\mathrm{IC}_{50}$ (half-maximal inhibitory concentration) for VY. They did not find any statistically significant differences in blood pressure or blood chemistry between VY and the control groups in normotensive subjects. Matsui et al. ${ }^{(153)}$ concluded that this very low degree of absorption was the result of hydrolysis from membrane-bound peptidases. They considered that alternatively VY was absorbed intact into the circulatory system and then rapidly accumulated in organs such as the aorta and kidney, resulting in a low and slow release of VY into the blood.

\section{Other bioactive peptides present in milk}

Milk, in particular, is known to be a rich source of bioactive peptides. The physiological properties and structural composition of the many milk-derived bioactive peptides have been comprehensively reviewed ${ }^{(52,154-157)}$ and many of the effects of such bioactive peptides contained within milk proteins, both bovine and human, are listed in Table 1. Such bioactive components of milk are encrypted within the major milk protein precursors and are released during the digestive process by enzymic proteolysis. A recent paper by Martínez-Maqueda et al. ${ }^{(158)}$ lists 134 different peptides with antihypertensive properties derived from a variety of plant and animal proteins, including forty-nine derived from milk. The principal mechanism of action for peptides with antihypertensive effects, as discussed above, is the inhibition of angiotensin-I-converting enzyme (ACE). ACE is a constituent enzyme of the reninangiotensin system (RAS), a mechanism that plays a crucial role in the regulation of blood pressure together with fluid and electrolyte balance ${ }^{(159)}$. Although the blood pressure-lowering capability of the peptides described by Martínez-Maqueda et $a l .{ }^{(158)}$ was reported as having been demonstrated in in vivo assays involving animal models (for example, SHR and humans), the different mechanisms of action that contribute to their antihypertensive effect still require further investigation. The absorption of ACE-inhibiting peptides in humans was reported by Martínez-Maqueda et al. ${ }^{(158)}$ for the peptide histidineleucine-proline-leucine-proline (HLPLP), just one of seventeen small ACE-inhibitory peptides studied by van Platerink et $a l .{ }^{(160)}$. An alternative to absorption suggested by Martínez-Maqueda et al. ${ }^{(158)}$ involves the action of small peptides on opioid receptors present in the gut wall. A large number of studies have focused on the opioid properties that many of these peptides exhibit and the physiological effects that these molecules might have (see Table 2). Dietary exogenous opioid molecules have been termed exorphins ${ }^{(161)}$ and as well as being in milk they have been found in a variety of other proteinaceous staple foods including gluten in cereals ${ }^{(162,163)}$ and $\mathrm{Hb}$ in meat ${ }^{(164,165)}$. From as early as $1979^{(166,167)}$, many of the bioactive peptides derived from milk, and casein in particular, have been demonstrated to have opioid properties such as those described in Table 2. Although exorphins may not be absorbed intact, their physiological influence resulting from their interaction with opioid receptors in the GIT is in little doubt. Several studies report that small opiateacting peptides released during digestion by proteolytic hydrolysis can affect intestinal function ${ }^{(168-170)}$.

The existence of three opioid receptors $(\mu, \delta$ and $\kappa)$ was described simultaneously by three different groups of researchers in $1973^{(171-173)}$ and have been exhaustively reviewed in the Handbook of Experimental Pharmacology ${ }^{(174)}$. It is supposed that the $\mu, \delta$ and $\kappa$ opioid receptors belong to the G-protein-coupled receptor 
Table 1. Examples of bioactive peptides derived from bovine milk proteins

\begin{tabular}{|c|c|c|c|c|c|}
\hline & Bioactive peptide & Protein precursor & $\begin{array}{l}\text { Amino acid } \\
\text { segment }\end{array}$ & Peptide sequence $\dagger$ & Bioactivity \\
\hline \multicolumn{6}{|c|}{ Bioactive peptides derived from casein precursors } \\
\hline 1 & $\alpha$-Casein exorphin & $\alpha_{S 1}$-Casein & f90-96 & RYLGYLE & Opioid agonist \\
\hline 2 & $\alpha$-Casein exorphin & $\alpha_{S 1}$-Casein & f90-95 & RYLGYL & Opioid agonist \\
\hline 3 & $\alpha$-Casein exorphin & $\alpha_{S 1}$-Casein & f91-96 & YLGYLE & Opioid agonist \\
\hline 4 & $\beta$-Casomorphin-11 & $\beta$-Casein & f60-70 & YPFPGPIPNSL & Opioid agonist \\
\hline 5 & $\beta$-Casomorphin-7 & $\beta$-Casein & f60-66 & YPFPGPI & Opioid agonist, immunomodulatory and ACE inhibitor \\
\hline 6 & $\beta$-Casomorphin-5 & $\beta$-Casein & f60-64 & YPFPG & Opioid agonist \\
\hline 7 & Casoxin 6 & $\mathrm{\kappa}$-Casein & $\mathrm{f} 33-38$ & SRYPSY $\cdot \mathrm{OCH}_{3}$ & Opioid antagonist \\
\hline 8 & Casoxin A & $\kappa$-Casein & $\mathrm{f} 35-42$ & YPSYGLNY & Opioid antagonist \\
\hline 9 & Casoxin B & $\mathrm{k}$-Casein & F58-61 & YPYY & Opioid antagonist \\
\hline 10 & Casoxin C & $\kappa$-Casein & $\mathrm{f} 25-34$ & YIPIQYVLSR & Opioid antagonist \\
\hline 11 & Casoplatelin & $\kappa$-Casein & $\mathrm{f} 106-116$ & MAIPPKKNQDK & Antithrombotic \\
\hline 12 & $\alpha_{S 1}$-Casokinin-5 & $\alpha_{S 1}$-Casein & f23-27 & FFVAP & ACE inhibitor \\
\hline 13 & $\alpha_{S_{1}}$-Casokinin-6 & $\alpha_{S 1}$-Casein & f194-199 & TTMPLW & Immunomodulatory and ACE inhibitor \\
\hline 14 & $\alpha_{S_{1}}$-Casokinin-7 & $\alpha_{S 1}$-Casein & $\mathrm{f} 28-34$ & FPEVFGK & ACE inhibitor \\
\hline 15 & $\beta$-Casokinin-7 & $\beta$-Casein & f177-183 & AVPYPQR & ACE inhibitor \\
\hline 16 & $\beta$-Casokinin-10 & $\beta$-Casein & f193-202 & YQQPVLGPVR & Immunomodulatory and ACE inhibitor \\
\hline 17 & Immunopeptide & $\beta$-Casein & f63-68 & PGPIPN & Immunomodulatory \\
\hline 18 & Immunopeptide & $\beta$-Casein & f191-193 & LLY & Immunomodulatory \\
\hline 19 & Casein phosphopeptide & $\alpha_{S 1}-$ Casein & $\mathrm{F} 43-58$ & DIGS*ES*TEDQAMEDIM & Ca binding and transport \\
\hline 20 & Casein phosphopeptide & $\alpha_{S 1}$-Casein & F59-79 & QMEAES*IS*S*S*EEIVPNS*VEQK & Ca binding and transport \\
\hline 21 & Casein phosphopeptide & $\beta$-Casein & $f 1-25$ & RELEELNVPGEIVES ${ }^{*} \mathrm{LS}^{*} \mathrm{~S}^{*} \mathrm{~S}^{*}$ EESITR & Ca binding and transport \\
\hline \multicolumn{6}{|c|}{ Bioactive peptides derived from whey protein precursors } \\
\hline 22 & Serorphin & Bovine serum albumin & f399-404 & YGFQNA & Opioid agonist \\
\hline 23 & $\alpha$-Lactorphin & $\alpha$-Lactalbumin & $550-53$ & $\mathrm{YGLF} \cdot \mathrm{NH}_{2}$ & Opioid agonist and ACE inhibitor \\
\hline 24 & $\beta$-Lactorphin & $\beta$-Lactoglobulin & f102-105 & YLLF $\cdot \mathrm{NH}_{2}$ & Opioid agonist and ACE inhibitor \\
\hline 25 & Lactoferricin & Lactoferrin $\ddagger$ & $\mathrm{f} 17-41$ & FKCRRWNRMKKLGAPSIT-CVRRAF & Immunomodulatory and antimicrobial \\
\hline 26 & $\beta$-Lactotensin & $\alpha$-Lactoglobulin & f146-149 & HIRL & lleum contraction \\
\hline 27 & Immunopeptide & $\alpha$-Lactalbumin & $f 50-51 f 18-19$ & YG & Immunopotentiation \\
\hline 28 & Immunopeptide & $\alpha$-Lactalbumin & $\mathrm{f} 18-20$ & YGG & Immunopotentiation \\
\hline 29 & Albutensin A & Bovine serum albumin & $\mathrm{f} 208-216$ & ALKAWSVAR & Ileum contraction and ACE inhibitor \\
\hline
\end{tabular}

$\mathrm{ACE}$, angiotensin-converting enzyme; $\mathrm{S}^{*}$, phosphoserin.

One-letter amino acid codes were used.

$\ddagger$ Lactoferrin is a neutrophil-derived glycoprotein found in secreted mammalian fluids ${ }^{(170)}$ 
Table 2. Exorphins: peptides derived from milk having opioid properties

\begin{tabular}{|c|c|c|c|c|c|}
\hline & Bioactive peptide & Protein precursor & Opioid receptor & Bioactivity & Physiological effect \\
\hline 1 & $\alpha$-Casein exorphin & $\alpha_{S_{1}}$-Casein & $\delta$ & Opioid agonist & In adults: \\
\hline 2 & $\alpha$-Casein exorphin & $\alpha_{S 1}$-Casein & $\delta$ & Opioid agonist & $\begin{array}{l}\text { Increases in intestinal transit } \\
\text { time } \dagger, \text { amino acid uptake } \\
\text { and water balance§ }\end{array}$ \\
\hline 3 & $\alpha$-Casein exorphin & $\alpha_{\mathrm{S} 1}$-Casein & $\delta$ & Opioid agonist & \\
\hline 4 & $\beta$-Casomorphin-11 & $\beta$-Casein & $\mu$ & Opioid agonist & \\
\hline 5 & $\beta$-Casomorphin-7 & $\beta$-Casein & $\mu$ & Opioid agonist & \\
\hline 6 & $\beta$-Casomorphin-5 & $\beta$-Casein & $\mu$ & Opioid agonist & Additionally in neonates: \\
\hline 7 & Serorphin & Bovine serum albumin & $\mu^{*}$ & Opioid agonist & $\begin{array}{l}\text { Analgesiall that results in } \\
\text { calmness and sleep }\end{array}$ \\
\hline 8 & $\alpha$-Lactorphin & $\alpha$-Lactalbumen & $\mu^{*}$ & Opioid agonist & \\
\hline 9 & $\beta$-Lactorphin & $\beta$-Lactoglobulin & $\mu^{*}$ & Opioid agonist & \\
\hline 10 & Casoxin 4 & $\kappa$-Casein & $\mu$ and $\kappa$ & Opioid antagonist & \\
\hline 11 & Casoxin 6 & $\kappa$-Casein & $\mu$ and $\kappa$ & Opioid antagonist & \\
\hline 12 & Casoxin A & $\kappa$-Casein & $\mu$ and $\kappa^{\star *}$ & Opioid antagonist & \\
\hline 13 & Casoxin B & $\kappa$-Casein & $\mu$ and $\kappa^{\star *}$ & Opioid antagonist & \\
\hline 14 & Casoxin C & $\kappa$-Casein & $\mu$ and $\kappa^{\star *}$ & Opioid antagonist & \\
\hline 15 & Casoxin D & $\alpha_{S 1}$-Casein & $\mu$ and $\delta^{\star \star}$ & Opioid antagonist & $\begin{array}{l}\text { Vasorelaxation and smooth } \\
\text { muscle contraction } \dagger \dagger\end{array}$ \\
\hline
\end{tabular}

${ }^{*}$ Represents opioid activity with low potency.

† Schulte-Frohlinde et al. ${ }^{(183)}$, Teschemacher et al. ${ }^{(178)}$, Froetschel ${ }^{(184)}$ and Allescher et al. ${ }^{(185)}$.

$\ddagger$ Brandsch et al. ${ }^{(186)}$.

$\S$ Daniel et al. ${ }^{(187)}$.

$\|$ Matthies et al. ${ }^{(188)}$ and Taira et al. ${ }^{(189)}$.

If Taira et al. ${ }^{(189)}$.

${ }^{\star *}$ Represents low affinity to this receptor.

†† Yoshikawa et al. ${ }^{(192)}$.

family and have seven transmembrane helices which are characteristic of the group ${ }^{(175)}$. All three of these receptors have been detected in the small intestine and are located in the myenteric plexus ${ }^{(176,177)}$.

Opioid receptor ligands are classified into two groups 'typical' and 'atypical' designated by Teschemacher et $a l^{(178)}$. The 'typical' peptides all originate from three endogenous precursor proteins pro-opiomelanocortin (endorphins), pro-enkephalin (enkephalins) and prodynorphin (dynorphins) ${ }^{(179)}$. All the typical opioid peptides share the same N-terminal amino acid sequence, YGGF. Although they can bind to more than one type of receptor, they usually have a greater affinity for just one, dynorphins for $\kappa$-receptors, the enkephalins for $\delta$-receptors and the endorphins for $\mu-, \delta$ - and $\epsilon$-receptors ${ }^{(180)}$. The 'atypical' receptor ligands originate from a variety of precursor proteins either endogenous or exogenous and, although their N-terminal amino acid sequence may vary, they all have a terminal tyrosine residue in common (all except opioid receptor ligands that originate from $\alpha$-casein) and another aromatic amino acid residue, such as tyrosine or phenylalanine, in the third or fourth position. The biological activity of these peptides is dependent upon the terminal tyrosine residue, as its absence eliminates all bioactivity ${ }^{(181)}$. A proline residue at position 2 also appears to be necessary for the correct orientation of the peptide when it binds to the opioid receptor ${ }^{(182)}$. Opioid antagonists have much in common with the 'atypical' agonists though they do not usually have a similar $\mathrm{N}$-terminal amino acid sequence. The antagonistic potency of naturally occurring milk-borne peptides is relatively low though some synthetic derivatives have very high potency and receptor selectivity. The synthetic alkaloid agonists naloxone and naltrexone are often used in opioid peptide research as inhibitory confirmation of the presence of an agonistic opioid receptor ligand.

Of the forty-nine antihypertensive peptides derived from milk listed by Martínez-Maqueda et $a l^{(158)}$, five have amino acid motifs of reported opioid agonists ${ }^{(178,183-189)}$. These opioid peptides might lower blood pressure through receptors expressed within the gut wall to bring about ACE inhibition, implying that no absorption is required ${ }^{(190)}$. Two of the other small peptides listed by MartínezMaqueda et $a l .{ }^{(158)}$ (attributed to Jiang et al. ${ }^{(191)}$ as having ACE-inhibitory properties) have amino acid motifs reported by Yoshikawa et al. ${ }^{(192)}$ to be opioid antagonists. Derived from $\mathrm{\kappa}$-casein there are four more peptides (casoxins) present in milk known to be opioid antagonists ${ }^{(192)}$. The small peptides listed by Martínez-Maqueda et al. ${ }^{(158)}$ are different in that they contain di- and tri-amino acid sequences that are reported to have antihypertensive properties (for example, tyrosine-proline (YP) and leucine-phenylalanine-phenylalanine (LLF)). It is possible that many of the listed peptides may be degraded by enzymic hydrolysis to release di- and tripeptides which may then be absorbed via the PepT1 peptide transporter.

\section{Opioid-acting peptides}

In a recent review, Hernández-Ledesma et al. ${ }^{(193)}$ also suggested that opioid receptors are probably involved with antihypertensive effects, citing $\alpha$-lactorphin, 
$\beta$-lactorphin and human casein-derived fragments as examples of peptides in which their antihypertensive effects are abolished by the opioid receptor antagonist naloxone. In earlier studies Nurminen et al. ${ }^{(194)}$ determined that following a single subcutaneous injection of the tetrapeptide YGLF, derived from $\alpha$-lactalbumin, both the systolic and diastolic blood pressures were lowered in SHR and normotensive rats. Using mesenteric arterial preparations Sipola et $a l .{ }^{(195)}$ proposed that the blood pressure-lowering effect of YGLF in SHR is mediated via vasodilation in mesenteric arteries following peripheral opioid receptor stimulation and subsequent NO release. Strangely, YGLF did not alter the vascular responses in the mesenteric arteries from age-matched normotensive Wistar-Kyoto rats ${ }^{(195)}$. Ovokinin(2-7) (RADHPF), another NO-dependent vasorelaxing peptide, isolated from a chymotryptic digest of ovalbumin, has also been demonstrated to lower the blood pressure of SHR and to have no effect on the blood pressure of normotensive Wistar-Kyoto rats ${ }^{(190)}$. Studies such as these suggest that such opioid peptides may lower blood pressure through receptors expressed in the GIT, implying that no absorption is required. Miguel et al. ${ }^{(196)}$ noted that mechanisms other than ACE inhibition have been reported to explain the antihypertensive effect of various peptide sequences, for example, vasodilation ${ }^{(197-199)}$ and antioxidant activity ${ }^{(200-202)}$.

Interestingly a local RAS has been reported to be present in the small intestine, with the key components being expressed at the gene and protein levels of the jejunal and ileal enterocytes ${ }^{(203)}$. Angiotensinogen, ACE, together with angiotensin I (AngI) and AngII receptors, are localised in the microvilli of the $\mathrm{BBM}^{(204-206)}$. ACE, a metalloproteinase, hydrolyses AngI (a decapeptide) to AngII (an octapeptide). The AngII released then binds to AngII receptors in the $\mathrm{BBM}^{(203,207)}$ and at low doses AngII stimulates jejunal $\mathrm{Na}$ and water absorption. At higher doses of AngII, fluid absorption is inhibited via an AngI receptor-dependent process ${ }^{(208)}$. Enterocyte-derived AngII is also involved in the regulation of $\mathrm{Na}^{+}$-D-glucose cotransporter 1 (SGLT1)-mediated intestinal glucose transport at the $\mathrm{BBM}^{(204)}$. Yoshioka et al. ${ }^{(209)}$ proposed that ACE associated with the BBM may function as a membrane-bound peptidase. A comparison of intestinal fluid absorption between male SHR and normotensive male controls has been reported, with enhanced fluid absorption in both hypertensive adults and in young SHR before hypertension has developed ${ }^{(210)}$. Na and fluid homeostasis is therefore abnormal in SHR compared with normotensive rats ${ }^{(211)}$, and in view of a possible relationship between high salt intake and hypertension ${ }^{(212)}$ it would appear possible that an abnormality in $\mathrm{Na}$ and fluid homeostasis may be significant in the development of hypertension in SHR and possibly in human hypertension ${ }^{(210)}$. By administering captopril intravenously or by bilateral nephrectomy, Dorey et al. ${ }^{(210)}$ demonstrated that the circulating RAS was not responsible for the high level of fluid transport in SHR as neither of these procedures suppressed fluid transport. However, the presence of the intestinal RAS was not known to these authors at the time, and $\mathrm{Na}$ and fluid transport across the gut wall, controlled by the local RAS, would not be affected by either procedure adopted by Dorey et al. ${ }^{(210)}$. As ACE inhibitors (for example, Ramipril) have been shown to inhibit human brush-border ACE activity ${ }^{(205)}$ it follows that the absorption of $\mathrm{Na}$ and fluid across the gut wall will be affected. Such changes are therefore consistent with the hypothesis that antihypertensive drugs and dietary bioactive peptides have an extracellular effect on the intestinal RAS by changing the passage of $\mathrm{Na}$ and fluid across the gut wall and thus lowering systemic blood pressure. This might explain why the lactotripeptides VPP and IPP have been shown to lower blood pressure ${ }^{(123)}$ with plasma concentrations below the effective concentration for ACE inhibition ${ }^{(125,144)}$

The nonpeptide (for example, captopril) and peptidomimetic dipeptide (for example, enalapril) ACE-inhibitory drugs are active-site-directed, competitive inhibitors with sub-nanomolar $\mathrm{K}_{\mathrm{i}}$ values of $10^{-10}-10^{-11(213)}$ that have been reported by many researchers to be transported across the gut wall via the PepT1 peptide transporter ${ }^{(214,215)}$. However, according to Brandsch et al. ${ }^{(142)}$, transport of these compounds remains a matter of controversy. Whichever way they are transported across the gut wall, the pharmacological effectiveness of these compounds lies in their absorption from the intestinal lumen and into the hepatic portal system to react directly with the cardiovascular RAS and is therefore not restricted to stimulating the extracellular intestinal RAS.

\section{Absorption of larger peptides}

Although the absorption into the enterocytes of di- and tripeptides has been demonstrated, there are conflicting views regarding the absorption of larger peptides ${ }^{(33,216)}$.

Many in vitro studies have demonstrated that milk is a rich source of bioactive peptides ${ }^{(34,57,154,157,217-220)}$; however, few peptides have been shown to be biologically active in vivo following the ingestion of milk or fermented milk products (i.e. it has not been ascertained whether the functional domains of milk proteins survive digestion and reach the blood in concentrations of any physiological significance ${ }^{(143)}$ ). For example, Petrilli et $a l^{(221)}$ demonstrated that $\beta$-casomorphins, the family of bioactive peptides derived from milk $\beta$-casein ${ }^{(222,223)}$, do not survive digestive degradation. In addition, Schmelzer et $a l .{ }^{(224)}$ determined that no significant amounts of $\beta$-casomorphins or other known bioactive peptides are formed during the peptic digestion of bovine $\beta$-casein under simulated gastric conditions. Vermeirssen et al. ${ }^{(20)}$ also came to a similar conclusion, stating that no intact transepithelial passage has been detected for these 
peptides. However, there are many papers outlining physiological effects/functions of milk-borne bioactive peptides $(33,50,52,56,57,150,154,157,168,170,220,225,226)$. The prevailing current opinion is that the majority of the known bioactive peptides do not pass into the bloodstream in meaningful amounts and that any known physiological effects are mediated through receptors on the intestinal wall $^{(57,143)}$.

One of the most quoted/misquoted papers on the subject is that of Gardner ${ }^{(227)}$ stating that it has been observed that large peptides or proteolysis-resistant proteins can enter the bloodstream, albeit in small amounts. However, Gardner did not give any direct evidence for the absorption of intact protein in humans; instead the following was offered in support of the hypothesis that intact proteins and macromolecular fragments of them may be absorbed:

(a) That antibodies to many food proteins and their immune complexes have been detected in the circulation of healthy individuals ${ }^{(228-232)}$. However, he qualified this statement by suggesting that such antibodies may arise through the intestinal immune system responding to luminal proteins rather than absorbed ones.

(b) That RIA techniques ${ }^{(233,234)}$ show the presence of orally administered proteins such as ovalbumin in the blood. However, referring back to the researchers cited by Gardner, Husby et al. ${ }^{(233)}$ fed ten children (aged 2.5-13 years) a test meal containing $2 \mathrm{ml}$ of raw egg and $10 \mathrm{ml}$ cows' milk per $\mathrm{kg}$ body weight through a gastric tube placed adjacent to the ligament of Treitz. Five of the children had been diagnosed with coeliac disease and the five controls were also suspected of having coeliac disease. Although they found ovalbumin in the plasma of three of the five coeliac patients and all five of the controls, the feeding conditions and all the experimental subjects being children, with or suspected of suffering from coeliac disease, suggest their results should be treated with caution. With respect to Jakobsson et al. ${ }^{(234)}$, the target protein was not found to be absorbed in all subjects. The protein $\alpha$-lactalbumin purified from human milk was not detected $(<5 \mu \mathrm{g} / \mathrm{l})$ in the serum of adult men, non-pregnant women or in the serum from formula-fed infants. However, $\alpha$-lactalbumin was found in serum from pregnant women, cord blood and from newborn non-fed infants.

(c) That intact or largely intact HRP was found in the blood of carp and trout ${ }^{(235,236)}$. However, it must be questioned as to whether observations in fish apply to adult humans. Interestingly, Heyman ${ }^{(58)}$ reported that during active cows' milk allergy there was an eightfold increase in the absorption of the bystander protein HRP and an alteration of the epithelial integrity. However, after several months on a cows' milk-free diet and during a symptom-free period the absorption of HRP and paracellular permeability returned to normal values, indicating that the increased intestinal permeability to antigens was not the primary cause of the condition ${ }^{(58)}$.

Further, Gardner ${ }^{(227)}$ cited the work of Walker et al. ${ }^{(237,238)}$ who studied the in vitro absorption of dietary antigen and antigen-antibody complexes to corroborate their hypothesis. This will be discussed in more detail below, relative to the work of Roberts et al. ${ }^{(115)}$. Another paper often quoted is that of Fiat et al. ${ }^{(239)}$ who cite Gardner ${ }^{(227)}$. Gardner describes the GIT as a major site of immunological competence, as substantial numbers of lymphocytes and macrophages are found throughout the intestinal lamina propria. He hypothesises that absorption occurs predominantly by transcellular endocytosis in the M-cells (or lymphoepithelial cells ${ }^{(240)}$ ) and that this allows subepithelial lymphocytes direct access to luminal antigens. Transcellular endocytosis occurs when protein molecules bind to receptors on the BBM, which are then encapsulated into phagolysosomes. Proteolysis in the phagolysosomes minimises the entry of intact bioactive peptides into the circulation, which Gardner ${ }^{(241)}$ states is likely to be deleterious. So, although antibodies to numerous food proteins may occur in the circulation of healthy individuals, this should not be taken as evidence for the presence of the original peptide antigens within the blood. Gardner also states that it is not yet possible to state with reliable accuracy what fraction of the protein will enter the circulation in macromolecular form.

Much more work has been undertaken since Gardner wrote his paper in $1988^{(227)}$, yet still little is known about the absorption of the larger bioactive peptides. Teschemacher et $a{ }^{(242)}$, in a classic review, suggested that $\beta$-casomorphins and their precursors have not been identified in the cardiovascular compartment in more than negligible concentrations and it is unlikely that they have any functional role in adult mammals outside the GIT. Teschemacher also states that enzymic degradation in the intestinal wall and in the blood appears to prevent the accumulation of peptides in plasma ${ }^{(242-244)}$. For example dipeptidyl-peptidase is one of the enzymes that effectively degrades $\beta$-casomorphins in plasma ${ }^{(222)}$ and in the intestinal brush border ${ }^{(245)}$. Meisel \& Fitzgerald $^{(170)}$ also point out that opioid casein fractions have not been detected in the plasma of adult mammals and that only in the neonate is the intestine permeable to casomorphins and their precursors. Teschemacher et al. ${ }^{(242)}$ and the reviews by Clare \& Swaisgood ${ }^{(154)}$, Gill et al. ${ }^{(246)}$ and Shah ${ }^{(155)}$ reach similar conclusions to that of Gardner $^{(227)}$. Froetschel ${ }^{(184)}$ found that there is no evidence to support the theory that opioid peptides, such as the $\beta$-casomorphins, are transported into the bloodstream to the brain, or that they can cross the blood-brain barrier. No bioactive peptides or their native proteins have any 
established physiological role though they do have a variety of physiological effects.

However, to demonstrate the physiological effects of the multitude of bioactive peptides, researchers have often introduced them directly into the blood $^{(247)}$, the cerebrospinal fluid ${ }^{(165,248,249)}$ or even directly into the brain $^{(250-252)}$. Conclusive evidence for the functional significance of milk-derived opioid peptides has not yet been presented ${ }^{(169)}$ and the effects demonstrated by researchers for isolated or synthesised peptides derived from milk represent evidence of a pharmacological activity and not of a physiological role.

Roberts et al. ${ }^{(115)}$ studied the effect of amino acid chain length on the absorption of biologically active peptides from the GIT. Studying the absorption of just three peptides of differing chain length (thyrotropin-releasing hormone, a tripeptide; luteinising hormone-releasing hormone, a decapeptide; and human insulin, a fifty-oneamino acid polypeptide), they concluded that large peptides' (sic) as large as fifty-one amino acids generated from dietary proteins can be absorbed intact through the intestine and produce biological effects at the tissue level. This conclusion has been quoted by many other researchers ${ }^{(20,116,120,121,126,144,253)}$.

A number of factors need to be considered, however, to critically test such a claim:

(a) The study of Roberts et al. ${ }^{(115)}$ was undertaken using rats. Although this is an accepted animal model for simple-stomached mammals in general, the results do not necessarily relate to humans.

(b) The polypeptides were administered into the small intestine of the animal distal to the pancreatic duct and level with the ligament of Treitz, effectively bypassing both gastric and pancreatic degradative hydrolysis.

(c) The authors stated that the absorptive capacity of the small intestine in the experimental animals was not assessed and that the animal received a surgical procedure which placed a feeding tube within the small intestine that 'may have altered gut permeability and absorption'. It is known, for example, that such a naso-ileal tube affects gastric emptying ${ }^{(254,255)}$, increases intestinal transit time ${ }^{(256)}$, can stimulate intestinal secretions ${ }^{(256,257)}$, and that the effect of a gastrointestinal tube on the absorption and secretion of other substances has not been fully investigated.

(d) Although Roberts et al. ${ }^{(115)}$ measured serum insulin in the plasma of the experimental animals they did not state if this compound was the human insulin administered enterally or native rat insulin. In addition they did not determine the serum levels of the peptides administered, only their physiological effect (i.e. for thyrotropin-releasing hormone by determining serum thyroid-stimulating hormone levels and for luteinising hormone-releasing hormone they determined serum follicle-stimulating hormone levels). They also did not rule out that the physiological effects may have been mediated directly via the gut lumen or through receptors on the BBM.

(e) Roberts et al. ${ }^{(115)}$ tested for the absorption of human insulin, which has a different amino acid sequence to that of rat insulin, and used a very large enteral dose of $25 \mathrm{mg}$ (avoiding both gastric and upper small intestine digestive hydrolysis) to produce the measurable physiological effect.

Considering the above, Roberts et al. ${ }^{(115)}$ may possibly have over-extrapolated their conclusions by assuming that: (a) the oral intake of dietary peptides would be the same as enteral administration; (b) that gastric and pancreatic hydrolysis of such dietary peptides would be negligible; and (c) that all dietary peptides resistant to digestive degradation would be absorbed from the small intestine to the same extent as their experimental peptides (human insulin, thyrotropin-releasing hormone and luteinising hormone-releasing hormone).

Jahan-Mihan et al. ${ }^{(111)}$ claim that the absorption of intact proteins and peptides was demonstrated after animals were exposed to an intraduodenal infusion of somatostatin and with an increased concentration of somatostatin found in the blood. The paper they cite in support of this conjecture is that of Rao et al. ${ }^{(258)}$, who demonstrated the absorption of radioisotope-labelled [ $\left.{ }^{125} \mathrm{I}\right]$ $\left[\mathrm{Tyr}^{11}\right]$ somatostatin-14 following its intraduodenal administration in anaesthetised adult and neonatal rats. Somatostain-14 is a peptide-inhibitory hormone containing fourteen amino acids and with a molecular mass of 1638 Da. Intraduodenally administered somatostatin- 14 has been shown to inhibit pancreatic secretions in rats ${ }^{(259)}$ and dogs ${ }^{(260,261)}$. Rao et al. ${ }^{(258)}$ demonstrated that intraduodenally administered $\left[{ }^{125} \mathrm{I}\right]\left[\mathrm{Tyr}^{11}\right]$ somatostatin- 14 rapidly disappeared from the duodenal lumen of both suckling and adult rats (half-life being $2 \mathrm{~min}$ ). The loss of radioactivity from the lumen coincided with its simultaneous appearance in the tissues of the duodenal wall, blood, liver and kidney. Using C 18 Bond Elut cartridges and HPLC no intact $\left[{ }^{125} \mathrm{I}\right]\left[\mathrm{Tyr}^{11}\right]$ somatostatin-14 was found in any of those tissues and suggests that the $\left[{ }^{125} \mathrm{I}\right]\left[\mathrm{Tyr}^{11}\right]$ somatostatin-14 was rapidly metabolised intraduodenally and that no somatostatin had been absorbed by the gut wall and transferred to the blood or other organs. Rao et al. ${ }^{(258)}$ suggest that the inhibition of pancreatic secretions observed by Sarfati \& Morisset ${ }^{(259)}$ in rats and of Konturek et al. ${ }^{(260,261)}$ in dogs is mediated by somatostatin receptors in the duodenal wall. The argument that deiodination may occur before intestinal absorption ${ }^{(262)}$ appears to be unfounded, as Rao et al. ${ }^{(258)}$ found no free ${ }^{125} \mathrm{I}$ in any of the tissues described and unlabelled somatostatin-14 disappeared from the duodenal lumen at the same rate as that of the labelled compound. Such results suggest that peptidases in the duodenal lumen 
and at the surface of the BBM were responsible for the metabolism of the somatostatin-14. Rao et al. ${ }^{(258)}$ also observed that the duodenal half-life for the $\left[{ }^{125} \mathrm{I}\right]\left[\mathrm{Tyr}^{11}\right]$ somatostatin-14 was longer for the neonatal rats than in the adult rats, suggesting that milk-borne somatostatin may be more hydrolytically stable and biologically active for longer in the gut of the neonate rat, protected by peptidase inhibitors within the milk $^{(258)}$.

Historically it has been claimed that various digestive enzymes are selectively absorbed intact from the intestinal lumen directly into the bloodstream ${ }^{(263-273)}$ via the superior mesenteric vein from where they are extracted by the pancreas during the passage of blood through the pancreatic capillary bed. Having reclaimed pancreatic digestive enzymes from the circulation it was hypothesised that they are then resecreted by the exocrine pancreas into the duodenum along with other components of pancreatic juice in what has been controversially described as enteropancreatic circulation ${ }^{(274-276)}$. While there is evidence of the absorption of small quantities of digestive enzymes from the small intestine (for example, $<0.2 \%$ pancreatic amylase ${ }^{(277,278)}$ ) such quantities are insufficient to support the existence of a physiologically significant enteropancreatic circulation mechanism ${ }^{(277-280)}$. Interestingly, Levitt et al. ${ }^{(277)}$ reported that the net flux of amylase was from the pancreas into the blood and not the other way round; evidence contrary to the theory that circulating enzymes can be reclaimed by the pancreas. Following the publication of two articles by Levitt and colleagues ${ }^{(277,279)}$ and another by Rosenblum et al. ${ }^{(278)}$ and the study by Rohr et al. $^{(280)}$, Rothman \& Grendell ${ }^{(281)}$ sought to justify their hypothesis by dismissing the contrary experimental evidence reported in the three papers. The authors of the four papers cited by Rothman \& Grendell ${ }^{(281)}$ vehemently defended their findings and reiterated there was no evidence to support the existence of a physiologically important enteropancreatic circulation of enzymes and a good deal of evidence to the contrary ${ }^{(279,282)}$. Rosenblum et $a l^{(283)}$ suggested that although further studies under different experimental conditions might modify their conclusions, those who champion the importance of enteropancreatic circulation should support their belief with new data. In an effort to reignite the enteropancreatic circulation debate, Rothman et al. ${ }^{(274)}$ published an extensive review citing many papers in support of their hypothesis.

One widely reported dietary protein that may be absorbed across the gut wall and enter the bloodstream intact is ovalbumin ${ }^{(284-288)}$. Ovalbumin is the predominant protein in egg white, it contains 385 amino acids, has a molecular mass of $46.4 \mathrm{kDa}^{(289)}$ and a cross-sectional diameter of $4 \mathrm{~nm}^{(290)}$. The intestinal absorption of ovalbumin is known to invoke systemic immunological tolerance ${ }^{(291)}$ and a mucosal secretion of $\operatorname{Ig} \mathrm{A}^{(292)}$. However, in individuals with food allergy, ovalbumin can also stimulate the development of IgE-mediated food allergy ${ }^{(293-295)}$.
Castell et $a l^{(296)}$ have suggested that the absorption of macromolecules, including intact proteins, may occur under specific circumstances and that this phenomenon could be involved in the pathophysiology of certain intestinal diseases (for example, cows' milk allergy and inflammatory bowel disease $)^{(5,58,296-298)}$.

\section{Oral delivery of pharmacologically active proteins and peptides}

Pharmacologically active proteins and peptides are currently emerging as an imperative part of various treatment protocols and in particular cancer therapeutics ${ }^{(299)}$. However, despite extensive research, the administration of therapeutic peptides and proteins orally remains a challenge for pharmaceutical industries and researchers. Acidity and high enzymic proteolysis within the GIT are significant barriers to the successful delivery of intact proteins/peptides to the targeted site. Gupta et al. ${ }^{(299)}$ emphasise in their recent review that low permeability of the intestinal barrier is also a factor adding to the low bioavailability of any orally delivered proteins and peptides. Added to which, the short circulatory half-life exhibited by such peptides in vivo requires them to be administered frequently, which in turn increases the cost of treatment and results in low patient compliance ${ }^{(300)}$. One solution to this is the development of nano-carrier-based delivery that protects therapeutic proteins from degradation. As the surface of these particles can be modified towards hydrophilic or lipophilic properties, these systems promise high enterocytic permeability. Gupta et al. ${ }^{(299)}$ have suggested that nano-encapsulated proteins and peptides may also have enhanced stability in vivo that leads to increased circulation half-lives so the active peptides can reach the target tissue in effective concentrations. However, despite this, there are currently only a few orally delivered peptide/protein biopharmaceutical systems available and continued research is required to reap the promised effectiveness of these systems.

Essential in the treatment of diabetes mellitus is the peptide hormone insulin, which is currently administered to sufferers via subcutaneous injections. For patients who require daily injections of insulin the development of a less invasive route of administration would increase their quality of life significantly. Although the oral administration of insulin meets this criterion, Kamei et al. ${ }^{(301)}$ point out that two barriers must be overcome: the impermeability of insulin through the epithelial membranes and local digestion and enzymic degradation. To overcome the poor pharmacokinetics of oral administered insulin cellpenetrating peptides (CPP) could deliver exogenous proteins into cells and have the potential to facilitate effective insulin permeation from the intestinal lumen into the systemic circulation. In their review Kamei et al. ${ }^{(301)}$ describe how the co-administration of insulin with the short hydrophilic peptide penetratin, a typical CPP, 
increased intestinal insulin bioavailability to $35 \%$. The development of more effective CPP requires further research at this time. Recently, Renukuntla et $a l^{(302)}$ renewed the debate on the barriers to the oral delivery of peptide and protein drugs and reviewed many of the novel pharmaceutical approaches to circumvent these barriers and enhance oral bioavailability of these macromolecules.

Although liposomes have been used for the past 30 years as carriers of proteins and peptides requiring protection from the deleterious effects of the GIT, Swaminathan \& Ehrhardt ${ }^{(303)}$ note that the majority of data generated has been from in vitro studies or from work using rodents. Even though many of these studies have demonstrated that liposomes are effective carriers, the extrapolation from such models to human pharmacotherapy is challenging. Recently, liposomes loaded into alginate-chitosan microspheres or hyaluronic acid gels have been found to be promising vectors in the oral administration of protein or peptide drugs ${ }^{(304)}$, for example, insulin delivery ${ }^{(305)}$.

\section{Absorption, distribution, metabolism and excretion}

Foltz et $a l .{ }^{(30)}$ have cautioned us all, stating that although peptide absorption and peptide stimulatory/inhibitory effects may have been demonstrated in vitro, ex vivo and in vivo evidence for the absorption of oligopeptides in humans is lacking. Although selected peptides (for example, C-terminal proline-containing peptides) exhibit resistance to luminal peptidases, they remain susceptible to brush-border and cytosolic peptidases so that only minor fragments are expected to reach the systemic circulation ${ }^{(30)}$. Knowing the plasma concentrations and kinetics of orally administered peptides is essential for planning meaningful studies to assess the bioactivity of dietary peptides. Foltz et al. ${ }^{(30)}$ have stated that it is only valid to propose in vivo efficacy for bioactive peptides when the peptide exhibits reasonable proteolytic stability and physiologically relevant absorption, distribution, metabolism and excretion (ADME) profiles. Currently there is a lack of scientific evidence demonstrating that peptides, originating from dietary sources, have absorption or plasma clearance profiles that result in acceptable bioavailability. Foltz et al. ${ }^{(30)}$ concur with others that ADME properties may be conducive to supporting peptide activity only under certain pathophysiological conditions such as food allergies or inflammatory bowel disease ${ }^{(46,58,294,306-309)}$. The majority of in vitro studies, to identify bioactive peptides, have been conducted at high micromolar and even millimolar concentrations with incubation times lasting as long as $24 \mathrm{~h}$. These conditions are often not realistic nor physiologically relevant ${ }^{(30)}$.

\section{Conclusion}

In conclusion there is little unequivocal evidence that larger peptides can cross the gut wall and enter the hepatic portal system in physiologically relevant concentrations.
The tissues of the GIT separate the internal environment from an exterior environment that contains, in addition to dietary nutrients, possible allergens, toxins and pathogens ${ }^{(1,2)}$. The intestinal epithelial layer is pervious to many compounds but is particularly selective in both the types and quantities of compounds that may be absorbed. To maintain the integrity of the mucosal barrier the GIT is an integral part of the body's immune system where the majority of the body's immune cells are located $^{(3,4)}$. Not all protein present in the intestinal lumen is fully hydrolysed by the time it reaches the small intestine and selective transport systems absorb many di- and tripeptides (with further intra-cellular digestion) which form the bulk of amino acids entering the hepatic portal system $^{(28)}$. Larger peptides, protein particulates and microbial cells may cross the gut wall, though only in very small quantities. Indeed, most peptides and proteins that are absorbed are hydrolysed by cytosolic peptidases and thus do not pass through the basolateral membrane intact ${ }^{(23)}$. Most of those that do are antigens that quickly interact with localised immune cells ${ }^{(2,40)}$. Proteins induced by oral immunisation inhibit the absorption of the antigen on rechallenge ${ }^{(273)}$. Any surviving peptides that are largely absorbed are broken down by vascular endothelial tissue peptidases and soluble plasma peptidases ${ }^{\text {(33) }}$.

Overall, there is little unequivocal evidence that dietary bioactive peptides, other than possibly di- and tripeptides, can cross the gut wall and enter the hepatic portal system in physiologically relevant concentrations ${ }^{(57,118,143)}$.

\section{Acknowledgements}

The manuscript was written by W. M. M.-W. with contributions from P. M. and B. R. S.

The authors report no conflicts of interest in the present review.

\section{References}

1. Bajaj-Elliott M \& Sanderson IR (2004) Structure and function of the gastrointestinal mucosa. In Oral Tolerance: The Responce of the Intestinal Mucosa to Dietary Antigens, pp. 1-13 [O Morteau, editor]. New York: Kluwer Academic/Plenum Publishers.

2. Sanderson IR \& Walker WA (1999) Part 1, section A(4). In Handbook of Mucosal Immunology, 2nd ed., pp. 41-48 [R Ogra and J Mestecky, editors]. San Diego: Academic Press.

3. Bevins CL, Martin-Porter E \& Ganz T (1999) Defensins and innate host defence of the gastrointestinal tract. Gut 271, 14038-14045.

4. Wehkamp J, Schmid M \& Stange EF (2007) Defensins and other antimicrobial peptides in inflammatory bowel disease. Curr Opin Gastroenterol 23, 370-378.

5. Sanderson IR \& Walker WA (1993) Uptake and transport of macromolecules by the intestine: possible role in clinical disorders. Gastroenterology 104, 622-639.

6. Matthews DM (1975) Intestinal absorption of peptides. Physiol Rev 55, 537-608. 
7. Cohnheim O (1901) Die Umwandlung des Eiweiss durch die Darmwand (The conversion of protein through the intestinal wall). $Z$ Physiol Chem 33, 451-465.

8. Abderhalden E, Körösy KV \& London ES (1907) Weitere Studien uber die normale Verdauung der Eiweißkörper im Magendarmkanal des Hundes (Further studies about the normal digestion of protein bodies in the gastrointestinal tract of the dog). Hoppe-Seylers Z Physiol Chem 53, $148-163$.

9. Kutscher F \& Seemann J (1901-1902) Zur Kenntniss der Verdauungsvorgange im Dunndarm. I (To the knowledge of the digestive system in the small intestine. I). Hoppe-Seylers Z Physiol Chem 34, 528-543.

10. Stevens BR (2010) Amino acid transport by epithelial membranes. In Epithelial Transport Physiology, pp. 353-378 [GA Gerencser, editor]. New York: Humana Press.

11. Newey H \& Smyth DH (1959) The intestinal absorption of some dipeptides. J Physiol 145, 48-56.

12. Adibi SA (1971) Intestinal transport of dipeptides in man: relative importance of hydrolysis and intact absorption. J Clin Invest 50, 2266-2275.

13. Adibi SA, Morse EL, Masilamani SS, et al. (1975) Evidence for 2 different modes of tripeptide disappearance in human intestine - uptake by peptide carrier systems and hydrolysis by peptide hydrolases. J Clin Invest 56, 1355-1363.

14. Ganapathy V \& Leibach FH (1983) Role of pH gradient and membrane potential in dipeptide transport in intestinal and renal brush-border membrane-vesicles from the rabbit - studies with l-carnosine and glycyl-L-proline. J Biol Chem 258, 4189-4192.

15. Fei YJ, Kanai Y, Nussberger S, et al. (1994) Expression cloning of a mammalian proton-coupled oligopeptide transporter. Nature 368, 563-566.

16. Brandsch M \& Brandsch C (2003) Intestinal transport of amino acids, peptides and proteins. In Progress in Research on Energy and Protein Metabolism, pp. 667-680 [WB Souffrant and CC Metges, editors]. Wageningen: Wageningen Academic Publishers.

17. Matthews DM, Craft IL, Geddes DM, et al. (1968) Absorption of glycine and glycine peptides from the small intestine of the rat. Clin Sci 35, 415-424.

18. Matthews DM \& Adibi SA (1976) Peptide absorption. Gastroenterology 71, 151-161.

19. Craft IL, Geddes D, Hyde CW, et al. (1968) Absorption and malabsorption of glycine and glycine peptides in man. Gut 9, 425-437.

20. Vermeirssen V, Van Camp J \& Verstraete W (2004) Bioavailability of angiotensin I converting enzyme inhibitory peptides. Br J Nutr 92, 357-366.

21. Daniel H (2004) Molecular and integrative physiology of intestinal peptide transport. Annu Rev Physiol 66, 361-384.

22. Yang CY, Dantzig AH \& Pidgeon C (1999) Intestinal peptide transport systems and oral drug availability. Pharm Res $\mathbf{1 6}$, 1331-1343.

23. Adibi SA (2003) Regulation of expression of the intestinal oligopeptide transporter (Pept-1) in health and disease. Am J Physiol Gastrointest Liver Physiol 285, G779-G788.

24. Rubio-Aliaga I \& Daniel H (2008) Peptide transporters and their roles in physiological processes and drug disposition. Xenobiotica 38, 1022-1042.

25. Daniel H, Morse EL \& Adibi SA (1992) Determinants of substrate affinity for the oligopeptide $/ \mathrm{H}^{+}$symporter in the renal brush-border membrane. J Biol Chem 267, 9565-9573.

26. Adibi SA (1997) The oligopeptide transporter (Pept-1) in human intestine: biology and function. Gastroenterology 113, 332-340.
27. Terada T, Shimada Y, Pan XY, et al. (2005) Expression profiles of various transporters for oligopeptides, amino acids and organic ions along the human digestive tract. Biochem Pharmacol 70, 1756-1763.

28. Hara H, Funabiki R, Iwata M, et al. (1984) Portal absorption of small peptides in rats under unrestrained conditions. J Nutr 114, 1122-1129.

29. Nussberger S, Steel A, Trotti D, et al. (1997) Symmetry of $\mathrm{H}^{+}$binding to the intra- and extracellular side of the $\mathrm{H}^{+}$-coupled oligopeptide cotransporter PepT1. J Biol Chem 272, 7777-7785.

30. Foltz M, van der Pijl PC \& Duchateau G (2010) Current in vitro testing of bioactive peptides is not valuable. $J$ Nutr 140, 117-118.

31. Ganapathy V, Ganapathy ME \& Leibach FH (2001) Intestinal transport of peptides and amino acids. In Gastrointestinal Transport: Molecular Physiology, Current Topics in Membranes, vol. 50, pp. 379-412 [KE Barrett and M Donowitz, editors]. San Diego: Academic Press.

32. Meredith D \& Boyd CAR (2000) Structure and function of eukaryotic peptide transporters. Cell Mol Life Sci 57, 754-778.

33. Silva SV \& Malcata FX (2005) Caseins as source of bioactive peptides. Int Dairy J 15, 1-15.

34. Meisel H (1997) Biochemical properties of bioactive peptides derived from milk proteins: potential nutraceuticals for food and pharmaceutical applications. Livest Prod Sci 50, 125-138.

35. Haque E, Chand R \& Kapila S (2009) Biofunctional properties of bioactive peptides of milk origin. Food Rev Int $\mathbf{2 5}$, $28-43$.

36. Deacon CF, Nauck MA, Toftnielsen M, et al. (1995) Both subcutaneously and intravenously administered glucagonlike peptide- 1 are rapidly degraded from the $\mathrm{NH}_{2}$-terminus in type-II diabetic-patients and in healthy-subjects. Diabetes 44, 1126-1131.

37. Gardner MLG (1998) Transmucosal passage of intact peptides. In Peptides in Mammalian Protein Metabolism: Tissue Utilization and Clinical Targeting, vol. 11, pp. 11-29 [GK Grimble and FRC Backwell, editors]. London: Portland Press.

38. Weaver LT \& Walker WA (1989) Uptake of macromolecules in the neonate. In Human Gastrointestinal Development, pp. 731-748 [E Lebenthal, editor]. New York: Raven Press.

39. Walker WA \& Isselbacher KJ (1974) Uptake and transport of macromolecules by intestine - possible role in clinical disorders. Gastroenterology 67, 531-550.

40. Ménard S, Cerf-Bensussan N \& Heyman M (2010) Multiple facets of intestinal permeability and epithelial handling of dietary antigens. Mucosal Immunol 3, 247-259.

41. Izcue A, Coombes JL \& Powrie F (2006) Regulatory $\mathrm{T}$ cells suppress systemic and mucosal immune activation to control intestinal inflammation. Immunol Rev $\mathbf{2 1 2}$, $256-271$

42. Strobel S \& Mowat AM (1998) Immune responses to dietary antigens: oral tolerance. Immunol Today 19, 173-181.

43. Travis S \& Menzies I (1992) Intestinal permeability: functional assessment and significance. Clin Sci 82, 471-488.

44. Bjarnason I, Macpherson A \& Hollander D (1995) Intestinal permeability: an overview. Gastroenterology 108, 1566-1581.

45. Gersemann M, Wehkamp J \& Stange EF (2012) Innate immune dysfunction in inflammatory bowel disease. J Intern Med 271, 421-428.

46. Ingersoll SA, Ayyadurai S, Charania MA, et al. (2012) The role and pathophysiological relevance of membrane transporter PepT1 in intestinal inflammation and inflammatory 
bowel disease. Am J Physiol Gastrointest Liver Physiol 302 G484-G492.

47. Shan L, Molberg O, Parrot I, et al. (2002) Structural basis for gluten intolerance in celiac sprue. Science 297, 2275-2279.

48. Shan L, Qiao SW, Arentz-Hansen H, et al. (2005) Identification and analysis of multivalent proteolytically resistant peptides from gluten: implications for celiac sprue. J Proteome Res 4, 1732-1741.

49. Heyman M, Grasset E, Ducroc R, et al. (1988) Antigen absorption by the jejunal epithelium of children with cow's milk allergy. Pediatr Res 24, 197-202.

50. Kitts DD \& Weiler K (2003) Bioactive proteins and peptides from food sources. Applications of bioprocesses used in isolation and recovery. Curr Pharm Des 9, 1309-1323.

51. Moughan PJ, Fuller MF, Han KS, et al. (2007) Food-derived bioactive peptides influence gut function. Int J Sport Nutr Exerc Metab 17, S5-S22.

52. Meisel H (2004) Multifunctional peptides encrypted in milk proteins. Biofactors 21, 55-61.

53. Rowan AM, Haggarty NW \& Ram S (2005) Milk biloactives: discovery and proof of concept. Aust J Dairy Technol 60, $114-120$

54. Wilkinson PC (1974) Surface and cell-membrane activities of leukocyte chemotactic factors. Nature 251, 58-60.

55. Miner-Williams W (2012) The protein composition of endogenous losses in the human gut. PhD thesis, Massey University, Palmerston North, New Zealand.

56. Rutherfurd-Markwick KJ \& Moughan PJ (2005) Bioactive peptides derived from food. J AOAC Int $\mathbf{8 8}, 955-966$.

57. Korhonen H \& Pihlanto A (2006) Bioactive peptides: production and functionality. Int Dairy J 16, 945-960.

58. Heyman M (2001) How dietary antigens access the mucosal immune system. Proc Nutr Soc 60, 419-426.

59. Mahe S, Messing B, Thuillier F, et al. (1991) Digestion of bovine-milk proteins in patients with a high jejunostomy. Am J Clin Nutr 54, 534-538.

60. Astwood JD, Leach JN \& Fuchs RL (1996) Stability of food allergens to digestion in vitro. Nat Biotechnol 14, 1269-1273.

61. Furuse M, Fujita K, Hiiragi T, et al. (1998) Claudin-1 and -2: novel integral membrane proteins localizing at tight junctions with no sequence similarity to occludin. J Cell Biol 141, 1539-1550.

62. Furuse M, Hirase T, Itoh M, et al. (1993) Occludin: a novel integral membrane protein localizing at tight junctions. J Cell Biol 123, 1777-1788.

63. Mandell KJ, McCall IC \& Parkos CA (2004) Involvement of the junctional adhesion molecule-1 (JAM1) homodimer interface in regulation of epithelial barrier function. $J$ Biol Chem 279, 16254-16262.

64. Ikenouchi J, Furuse M, Furuse K, et al. (2005) Tricellulin constitutes a novel barrier at tricellular contacts of epithelial cells. J Cell Biol 171, 939-945.

65. Gebbers JO \& Laissue JA (1989) Immunologic structures and functions of the gut. Schweizer Archiv Fur Tierheilkunde 131, 221-238.

66. Lennernäs H (2007) Intestinal permeability and its relevance for absorption and elimination. Xenobiotica 37, 1015-1051.

67. Madara JL (1990) Maintenance of the macromolecular barrier at cell extrusion sites in intestinal epithelium: physiological rearrangement of tight junctions. J Membr Biol 116, $177-184$.

68. Shimizu M, Tsunogai M \& Arai S (1997) Transepithelial transport of oligopeptides in the human intestinal cell. Caco-2. Peptides 18, 681-687.

69. Shen WC, Wan JS \& Ekrami H (1992) (3) Enhancement of polypeptide and protein-absorption by macromolecular carriers via endocytosis and transcytosis. Adv Drug Deliver $\operatorname{Rev} \mathbf{8}, 93-113$.

70. Van Niel G, Mallegol J, Bevilacqua C, et al. (2003) Intestinal epithelial exosomes carry MHC class II/peptides able to inform the immune system in mice. Gut 52, 1690-1697.

71. Bockman DE \& Winborn WB (1966) Light and electron microscopy of intestinal ferritin absorption. Observations in sensitized and nonsensitized hamsters (Mesocricetus auratus). Anat Rec 155, 603-621.

72. Volkheimer G (1964) Permeability of the intestinal mucous membrane to large corpuscular elements (Herbst effect). Z Gastroenterol 2, 57-67.

73. Weiner ML (1988) Intestinal transport of some macromolecules in food. Food Chem Toxicol 26, 867-880.

74. Agar WT, Hird FJR \& Sidhu GS (1953) The active absorption of amino acids by the intestine. J Physiol 121, 255-263.

75. Wiggans DS \& Johnston JM (1959) The absorption of peptides. Biochim Biophys Acta 32, 69-73.

76. Hueckel HJ \& Rogers QR (1970) Urinary excretion of hydroxyproline-containing peptides in man, rat, hamster, dog and monkey after feeding gelatin. Comp Biochem Physiol 32, 7-16.

77. Hellier MD, Holdsworth CD, McColl I, et al. (1972) Dipeptide absorption in man. Gut 13, 965-969.

78. Boullin DJ, Crampton RF, Heading CE, et al. (1973) Intestinal absorption of dipeptides containing glycine, phenylalanine, proline, $\beta$-alanine or histidine in rat. Clin Sci Mol Med 45, 849-858.

79. Adibi SA (1976) Intestinal phase of protein assimilation in man. Am J Clin Nutr 29, 205-215.

80. Silk DBA, Perrett D, Webb JPW, et al. (1974) Absorption of 2 tripeptides by human small intestine: a study using a perfusion technique. Clin Sci Mol Med 46, 393-402.

81. Hellier MD, Holdsworth CD, Perrett D, et al. (1972) Intestinal dipeptide transport in normal and cystinuric subjects. Clin Sci 43, 659-668.

82. Silk DBA, Perrett D \& Clark ML (1975) Jejunal and ileal absorption of dibasic amino acids and an argininecontaining dipeptide in cystinuria. Gastroenterology $\mathbf{6 8}$ $1426-1432$.

83. Asatoor AM, Cheng B, Edwards KDG, et al. (1970) Intestinal absorption of two dipeptides in Hartnup disease. Gut 11, 380-387.

84. Tarlow MJ, Thomas AJ, Seakins JWT, et al. (1972) Absorption of amino acids and peptides in a child with a variant of Hartnup disease and coexistent celiac disease. Arch Dis Child 47, 798-803.

85. Adibi SA \& Morse EL (1977) Number of glycine residues which limits intact absorption of glycine oligopeptides in human jejunum. J Clin Invest 60, 1008-1016.

86. Chung YC, Silk DBA \& Kim YS (1979) Intestinal transport of a tetrapeptide, L-leucylglycylglycylglycine, in rat small intestine in vivo. Clin Sci 57, 1-11.

87. Burston D, Taylor E \& Matthews DM (1979) Intestinal handling of two tetrapeptides by rodent small intestine in vitro. Biochim Biophys Acta 353, 175-178.

88. Addison JM, Burston D, Payne JW, et al. (1975) Evidence for active transport of tripeptides by hamster jejunum in vitro. Clin Sci Mol Med 49, 305-312.

89. Kerchner GA \& Geary LE (1983) Studies on the transport of enkephalin-like oligopeptides in rat intestinal mucosa. J Pharmacol Exp Ther 226, 33-38.

90. Matthews DM \& Payne JW (1980) Current Topics in Membrane and Transport, vol. 14. New York: Academic Press.

91. Rogers CS, Heading CE \& Wilkinson S (1980) Absorption of 2 tyrosine containing tetrapeptides from the ileum of the rat. IRCS Med Sci Biochem 8, 648-649. 
92. Langguth P, Bohner V, Biber J, et al. (1994) Metabolism and transport of the pentapeptide metkephamid by brush-border membrane-vesicles of rat intestine. J Pharm Pharmacol 46, 34-40.

93. Fricker G, Bruns C, Munzer J, et al. (1991) Intestinalabsorption of the octapeptide SMS-201-995 visualized by fluorescence derivatization. Gastroenterology 100, 1544-1552.

94. Takaori K, Burton J \& Donowitz M (1986) The transport of an intact oligopeptide across adult mammalian jejunum. Biochem Biophys Res Commun 137, 682-687.

95. Lundin S \& Vilhardt H (1986) Absorption of 1-deamino8-D-arginine vasopressin from different regions of the gastrointestinal tract in rabbits. Acta Endocrinol 112, 457-460.

96. Amoss M, Rivier J \& Guillemin R (1972) Release of gonadotropins by oral administration of synthetic LRF or a tripeptide fragment of LRF. J Clin Endocrinol Metab 35, $175-177$.

97. Ptachcinski RJ, Burckart GJ \& Venkataramanan R (1985) Cyclosporine. Drug Intell Clin Pharm 19, 90-100.

98. Drewe J, Meier R, Vonderscher J, et al. (1992) Enhancement of the oral absorption of cyclosporine in man. Br J Clin Pharmacol 34, 60-64.

99. Walker WA, Cornell R, Davenport LM, et al. (1972) Macromolecular absorption. Mechanism of horseradish peroxidase uptake and transport in adult and neonatal rat intestine. J Cell Biol 54, 195-205.

100. Heyman M, Ducroc R, Desjeux JF, et al. (1982) Horseradish peroxidase transport across adult rabbit jejunum in vitro. Am J Physiol 242, G558-G564.

101. Neutra MR, Phillips TL, Mayer EL, et al. (1987) Transport of membrane-bound macromolecules by M-cells in follicleassociated epithelium of rabbit Peyer patch. Cell Tissue Res 247, 537-546.

102. Weltzin R, Luciajandris P, Michetti P, et al. (1989) Binding and transepithelial transport of immunoglobulins by intestinal M-cells: demonstration using monoclonal IgA antibodies against enteric viral proteins. J Cell Biol 108, 1673-1685.

103. Keljo D \& Hamilton JR (1983) Quantitative determination of macromolecular transport rate across intestinal Peyer's patches. Am J Physiol 244, G637-G644.

104. Hemmings C, Hemmings WA, Patey AL, et al. (1977) Ingestion of dietary protein as large molecular mass degradation products in adult rats. Proc Royal Soc Lond B Biol Sci 198, $439-453$.

105. Hemmings WA \& Williams EW (1978) Transport of large breakdown products of dietary protein through the gut wall. Gut 19, 715-723.

106. Hemmings WA \& Williams EW (1976) The use of direct deposition electron microscope autoradiography in studies of protein transport. J Microsc 106, 131-143.

107. Jones EA \& Waldmann TA (1971) Mechanism of intestinal uptake and transcellular transport of IgG in neonatal rat. Gut 12, 855-856.

108. Mostov KE (1994) Transepithelial transport of immunoglobulins. Annu Rev Immunol 12, 63-84.

109. Bloch KJ, Wright JA, Bishara SM, et al. (1988) Uptake of polypeptide fragments of proteins by rat intestine in vitro and in vivo. Gastroenterology 95, 1272-1278.

110. Phelan M \& Kerins D (2011) The potential role of milkderived peptides in cardiovascular disease. Food Funct 2, 153-167.

111. Jahan-Mihan A, Luhovyy BL, El Khoury D, et al. (2011) Dietary proteins as determinants of metabolic and physiologic functions of the gastrointestinal tract. Nutrients 3, 574-603.

112. Meisel H (2001) Bioactive peptides from milk proteins: a perspective for consumers and producers. Aust J Dairy Technol 56, 83-92.
113. Agyei D \& Danquah MK (2012) Rethinking food-derived bioactive peptides for antimicrobial and immunomodulatory activities. Trends Food Sci Technol 23, 62-69.

114. Agyei D \& Danquah MK (2011) Industrial-scale manufacturing of pharmaceutical-grade bioactive peptides. Biotechnol Adv 29, 272-277.

115. Roberts PR, Burney JD, Black KW, et al. (1999) Effect of chain length on absorption of biologically active peptides from the gastrointestinal tract. Digestion 60, 332-337.

116. Erdmann K, Cheung BWY \& Schroder H (2008) The possible roles of food-derived bioactive peptides in reducing the risk of cardiovascular disease. J Nutr Biochem 19 , 643-654.

117. Foltz M, Cerstiaens A, van Meensel A, et al. (2008) The angiotensin converting enzyme inhibitory tripeptides Ile-Pro-Pro and Val-Pro-Pro show increasing permeabilities with increasing physiological relevance of absorption models. Peptides 29, 1312-1320.

118. Séverin S \& Xia WS (2005) Milk biologically active components as nutraceuticals: review. Crit Rev Food Sci Nutr 45, 645-656.

119. Nakamura Y, Yamamoto N, Sakai K, et al. (1995) Antihypertensive effect of sour milk and peptides isolated from it that are inhibitors to angiotensin I-converting enzyme. J Dairy Sci 78, 1253-1257.

120. Robert MC, Razaname A, Mutter M, et al. (2004) Peptides derived from sodium caseinate hydrolysates produced by Lactobacillus helveticus NCC 2765. J Agric Food Chem 52, 6923-6931.

121. Zaloga GP \& Siddiqui RA (2004) Biologically active dietary peptides. Mini Rev Med Chem 4, 815-821.

122. Miguel M, Muguerza B, Sanchez E, et al. (2005) Changes in arterial blood pressure in hypertensive rats caused by longterm intake of milk fermented by Enterococcus faecalis CECT 5728. Br J Nutr 94, 36-43.

123. Mizuno S, Matsuura K, Gotou T, et al. (2005) Antihypertensive effect of casein hydrolysate in a placebo-controlled study in subjects with high-normal blood pressure and mild hypertension. Br J Nutr 94, 84-91.

124. Fitzgerald RJ \& Murray BA (2006) Bioactive peptides and lactic fermentations. Int J Dairy Technol 59, 118-125.

125. Foltz M, Meynen EE, Bianco V, et al. (2007) Angiotensin converting enzyme inhibitory peptides from a lactotripeptide-enriched milk beverage are absorbed intact into the circulation. J Nutr 137, 953-958.

126. Escudero E, Sentandreu MA, Arihara K, et al. (2010) Angiotensin I-converting enzyme inhibitory peptides generated from in vitro gastrointestinal digestion of pork meat. J Agric Food Chem 58, 2895-2901.

127. Muguerza B, Ramos M, Sanchez E, et al. (2006) Antihypertensive activity of milk fermented by Enterococcus faecalis strains isolated from raw milk. Int Dairy J 16, 61-69.

128. Nakamura T, Mizutani J, Sasaki K, et al. (2009) Beneficial potential of casein hydrolysate containing Val-Pro-Pro and Ile-Pro-Pro on central blood pressure and hemodynamic index: a preliminary study. J Med Food 12, 1221-1226.

129. Hata Y, Yamamoto M, Ohni M, et al. (1996) Placebocontrolled study of the effect of sour milk on blood pressure in hypertensive subjects. Am J Clin Nutr 64, 767-771.

130. Sano J, Ohki K, Higuchi T, et al. (2005) Effect of casein hydrolysate, prepared with protease derived from Aspergillus oryzae, on subjects with high-normal blood pressure or mild hypertension. J Med Food $\mathbf{8}, 423-430$.

131. Seppo L, Jauhiainen T, Poussa T, et al. (2003) A fermented milk high in bioactive peptides has a blood pressurelowering effect in hypertensive subjects. Am J Clin Nutr 77, 326-330. 
132. Jauhiainen $\mathrm{T}$, Vapaatalo H, Poussa $\mathrm{T}$, et al. (2005) Lactobacillus helveticus fermented milk lowers blood pressure in hypertensive subjects in 24-h ambulatory blood pressure measurement. Am J Hypertens 18, 1600-1605.

133. Xu J-Y, Qin L-Q, Wang P-Y, et al. (2008) Effect of milk tripeptides on blood pressure: a meta-analysis of randomized controlled trials. Nutrition 24, 933-940.

134. Boelsma E \& Kloek J (2009) Lactotripeptides and antihypertensive effects: a critical review. Br J Nutr 101, 776-786.

135. Masuda O, Nakamura Y \& Takano T (1996) Antihypertensive peptides are present in aorta after oral administration of sour milk containing these peptides to spontaneously hypertensive rats. J Nutr 126, 3063-3068.

136. Nilsson D, Fagerholm U \& Lennernas H (1994) The influence of net water absorption on the permeability of antipyrine and levodopa in the human jejunum. Pharm Res 11, 1540-1544.

137. Lennernäs H, Ahrenstedt $\mathrm{O}$ \& Ungell AL (1994) Intestinal drug absorption during induced net water absorption in man: a mechanistic study using antipyrine, atenolol and enalaprilat. Br J Clin Pharmacol 37, 589-596.

138. Fagerholm U, Nilsson D, Knutson L, et al. (1999) Jejunal permeability in humans in vivo and rats insitu: investigation of molecular size selectivity and solvent drag. Acta Physiol Scand 165, 315-324.

139. Satake M, Enjoh M, Nakamura Y, et al. (2002) Transepithelial transport of the bioactive tripeptide, Val-Pro-Pro, in human intestinal Caco-2 cell monolayers. Biosci Biotechnol Biochem 66, 378-384.

140. Camenisch G, Alsenz J, van de Waterbeemd H, et al. (1998) Estimation of permeability by passive diffusion through Caco-2 cell monolayers using the drugs' lipophilicity and molecular weight. Eur J Pharm Sci 6, 317-324.

141. Daniel H \& Herget M (1997) Cellular and molecular mechanisms of renal peptide transport. Am J Physiol 273, F1-F8.

142. Brandsch M, Knutter I \& Bosse-Doenecke E (2008) Pharmaceutical and pharmacological importance of peptide transporters. J Pharm Pharmacol 60, 543-585.

143. Picariello G, Ferranti P, Fierro O, et al. (2010) Peptides surviving the simulated gastrointestinal digestion of milk proteins: biological and toxicological implications. J Chromatogr B Analyt Technol Biomed Life Sci 878, 295-308.

144. van der Pijl PC, Kies AK, Ten Have GAM, et al. (2008) Pharmacokinetics of proline-rich tripeptides in the pig. Peptides 29, 2196-2202.

145. van Platerink CJ, Janssen HGM \& Haverkamp J (2007) Development of an at-line method for the identification of angiotensin-I inhibiting peptides in protein hydrolysates. J Chromatogr B Analyt Technol Biomed Life Sci 846, $147-154$.

146. Korhonen H (2009) Milk-derived bioactive peptides: from science to applications. J Funct Food 1, 177-187.

147. Ricci I, Artacho R \& Olalla M (2010) Milk protein peptides with angiotensin I-converting enzyme inhibitory (ACEI) activity. Crit Rev Food Sci Nutr 50, 390-402.

148. Fitzgerald RJ, Murray BA \& Walsh DJ (2004) Hypotensive peptides from milk proteins. J Nutr 134, 980S-988S.

149. Matsufuji H, Matsui T, Seki E, et al. (1994) Angiotensin I-converting enzyme-inhibitory peptides in an alkaline protease hydrolyzate derived from sardine muscle. Biosci Biotechnol Biochem 58, 2244-2245.

150. Yamamoto N, Ejiri M \& Mizuno S (2003) Biogenic peptides and their potential use. Curr Pharm Des 9, 1345-1355.

151. Li GH, Le GW, Shi YH, et al. (2004) Angiotensin I-converting enzyme inhibitory peptides derived from food proteins and their physiological and pharmacological effects. Nutr Res 24, 469-486.
152. Gobbetti M, Minervini F \& Rizzello CG (2004) Angiotensin I-converting-enzyme-inhibitory and antimicrobial bioactive peptides. Int J Dairy Technol 57, 173-188.

153. Matsui T, Tamaya K, Seki E, et al. (2002) Val-Tyr as a natural antihypertensive dipeptide can be absorbed into the human circulatory blood system. Clin Exp Pharmacol Physiol 29, 204-208.

154. Clare DA \& Swaisgood HE (2000) Bioactive milk peptides: a prospectus. J Dairy Sci 83, 1187-1195.

155. Shah NP (2000) Effects of milk-derived bioactives: an overview. Br J Nutr 84, S3-S10.

156. Lonnerdal B (2003) Nutritional and physiologic significance of human milk proteins. Am J Clin Nutr 77, 1537S-1543S.

157. Meisel H (2005) Biochemical properties of peptides encrypted in bovine milk proteins. Curr Med Chem 12, 1905-1919.

158. Martínez-Maqueda D, Miralles B, Recio I, et al. (2012) Antihypertensive peptides from food proteins: a review. Food Funct 3, 350-361.

159. Fitzgerald RJ \& Meisel H (2000) Milk protein-derived peptide inhibitors of angiotensin-I-converting enzyme. $\mathrm{BrJ}$ Nutr 84, S33-S37.

160. van Platerink CJ, Janssen HGM, Horsten R, et al. (2006) Quantification of ACE inhibiting peptides in human plasma using high performance liquid chromatographymass spectrometry. J Chromatogr B Analyt Technol Biomed Life Sci 830, 151-157.

161. Klee WA, Zioudrou C \& Streaty RA (1978) Endorphins in Mental Health Research. New York: Macmillan.

162. Fukudome S \& Yoshikawa M (1992) Opioid peptides derived from wheat gluten: their isolation and characterization. FEBS Lett 296, 107-111.

163. Fanciulli G, Dettori A, Demontis MP, et al. (2005) Gluten exorphin B5 stimulates prolactin secretion through opioid receptors located outside the blood-brain barrier. Life Sci 76, 1713-1719.

164. Ivanov VT, Karelin AA, Philippova MM, et al. (1997) Hemoglobin as a source of endogenous bioactive peptides: the concept of tissue-specific peptide pool. Biopolymers $4 \mathbf{3}$, $171-188$.

165. Zhao Q, Garreau I, Sannier F, et al. (1997) Opioid peptides derived from hemoglobin: hemorphins. Biopolymers 43 , 75-98.

166. Brantl V, Teschemacher H, Henschen A, et al. (1979) Novel opioid peptides derived from casein ( $\beta$-casomorphins). 1. Isolation from bovine casein peptone. Hoppe Seylers Z Physiol Chem 360, 1211-1216.

167. Zioudrou C, Streaty RA \& Klee WA (1979) Opioid peptides derived from food proteins - exorphins. J Biol Chem 254, 2446-2449.

168. Teschemacher H (2003) Opioid receptor ligands derived from food proteins. Curr Pharm Des 9, 1331-1344.

169. Teschemacher H, Koch G \& Brantl V (1997) Milk proteinderived opioid receptor ligands. Biopolymers 43, 99-117.

170. Meisel H \& Fitzgerald RJ (2000) Opioid peptides encrypted in intact milk protein sequences. Br J Nutr 84, S27-S31.

171. Simon EJ, Hiller JM \& Edelman I (1973) Stereospecific binding of potent narcotic analgesic $\left[{ }^{3} \mathrm{H}\right]$ etorphine to rat-brain homogenate. Proc Natl Acad Sci USA 70, 1947-1949.

172. Pert CB \& Snyder SH (1973) Opiate receptor: demonstration in nervous tissue. Science 179, 1011-1014.

173. Terenius L (1973) Characteristics of the receptor for narcotic analgesics in synaptic plasma membrane fraction from rat brain. Acta Pharmacol Toxicol 33, 377-384.

174. Mansour A \& Watson SJ (1993) Handbook of Experimental Pharmacology, vol. 104/I. Berlin: Springer. 
175. Satoh M \& Minami M (1995) Molecular pharmacology of the opioid receptors. Pharmacol Ther 68, 343-364.

176. Nishimura E, Buchan AMJ \& McIntosh CHS (1986) Autoradiographic localization of $\mu$ - and $\delta$-type opioid receptors in the gastrointestinal tract of the rat and guinea-pig. Gastroenterology 91, 1084-1094.

177. Karras PJ \& North RA (1981) Acute and chronic effects of opiates on single neurons of the myenteric-plexus. J Pharmacol Exp Ther 217, 70-80.

178. Teschemacher H, Koch G \& Brantl V (1994) Milk protein derived atypical peptides and related compounds with opioid antagonist activity (review). In $\beta$-Casomorphins and Related Peptides: Recent Developments, pp. 3-17 [V Brantl and H Teschemacher, editors]. Weinheim: VCH.

179. Höllt V (1986) Opioid peptide processing and receptor selectivity. Annu Rev Pharmacol Toxicol 26, 59-77.

180. Paterson SJ, Robson LE \& Kosterlitz HW (1983) Classification of opioid receptors. Br Med Bull 39, 31-36.

181. Chang KJ, Killian A, Hazum E, et al. (1981) Morphiceptin (NH4-Tyr-Pro-Phe-Pro-ConH2): a potent and specific agonist for morphine $(\mathrm{Mu})$ receptors. Science 212, 75-77.

182. Mierke DF, Nossner G, Schiller PW, et al. (1990) Morphiceptin analogs containing 2-aminocyclopentane carboxylic-acid as a peptidomimetic for proline. Int J Pept Protein Res 35, 35-45.

183. Schulte-Frohlinde E, Schimd R, Brantl V, et al (1994) Effect of bovine $\beta$-casomorphins-4-amide on gastrointestinal transit and pancreatic endocrine function in man. In $\beta$-Casomorphins and Related Peptides: Recent Developments, pp. 155-160 [V Brantl and H Teschemacher, editors]. Weinheim: $\mathrm{VCH}$.

184. Froetschel MA (1996) Bioactive peptides in digesta that regulate gastrointestinal function and intake. J Anim Sci 74, 2500-2508.

185. Allescher HD, Storr M, Brechmann C, et al. (2000) Modulatory effect of endogenous and exogenous opioids on the excitatory reflex pathway of the rat ileum. Neuropeptides 34, 62-68.

186. Brandsch M, Brust P, Neubert K, et al (1994) Evidence for a functional significance of natural $\beta$-casomorphins. $\beta$-Casomorphins: chemical signals of intestinal transport systems. In $\beta$-Casomorphins and Related Peptides: Recent Developments, pp. 207-219 [V Brantl and H Teschemacher, editors]. Weinheim: $\mathrm{VCH}$.

187. Daniel H, Vohwinkel M \& Rehner G (1990) Effect of casein and $\beta$-casomorphins on gastrointestinal motility in rats. J Nutr 120, 252-257.

188. Matthies H, Stark H, Hartrodt B, et al. (1984) Derivatives of $\beta$-casomorphins with high analgesic potency. Peptides 5, $463-470$.

189. Taira T, Hilakivi LA, Aalto J, et al. (1990) Effect of $\beta$-casomorphin on neonatal sleep in rats. Peptides 11, $1-4$.

190. Yamada Y, Matoba N, Usui H, et al. (2002) Design of a highly potent anti-hypertensive peptide based on ovokinin(2-7). Biosci Biotechnol Biochem 66, 1213-1217.

191. Jiang Z, Tian B, Brodkorb A, et al. (2010) Production, analysis and in vivo evaluation of novel angiotensin-Iconverting enzyme inhibitory peptides from bovine casein. Food Chem 123, 779-786.

192. Yoshikawa M, Tani F, Shiota H, et al (1994) Casoxin D, an opioid antagonist ileum-contracting/vasorelaxing peptide derived from human $\alpha_{\mathrm{s} 1}$-casein. In $\beta$-Casomorphins and Related Peptides: Recent Developments, pp. 43-48 [V Brantl and $\mathrm{H}$ Teschemacher, editors]. Weinheim: $\mathrm{VCH}$.

193. Hernández-Ledesma B, del Mar Contreras M \& Recio I (2011) Antihypertensive peptides: production, bioavailability and incorporation into foods. Adv Colloid Interface Sci 165, 23-35.

194. Nurminen ML, Sipola M, Kaarto H, et al. (2000) $\alpha$-Lactorphin lowers blood pressure measured by radiotelemetry in normotensive and spontaneously hypertensive rats. Life Sci 66, 1535-1543.

195. Sipola M, Finckenberg P, Vapaatalo H, et al. (2002) $\alpha$-Lactorphin and $\beta$-lactorphin improve arterial function in spontaneously hypertensive rats. Life Sci 71, 1245-1253.

196. Miguel M, Gómez-Ruiz JÁ, Recio I, et al. (2010) Changes in arterial blood pressure after single oral administration of milk-casein-derived peptides in spontaneously hypertensive rats. Mol Nutr Food Res 54, 1422-1427.

197. Miguel M, Manso MA, López-Fandiño R, et al. (2007) Vascular effects and antihypertensive properties of к-casein macropeptide. Int Dairy J 17, 1473-1477.

198. Miguel M, Manso M, Aleixandre A, et al. (2007) Vascular effects, angiotensin I-converting enzyme (ACE)-inhibitory activity, and anti hypertensive properties of peptides derived from egg white. J Agric Food Chem 55 , 10615-10621.

199. Miguel M, Alvarez Y, López-Fandiño R, et al. (2007) Vasodilator effects of peptides derived from egg white proteins. Regul Pept 140, 131-135.

200. Dávalos A, Miguel M, Bartolome B, et al. (2004) Antioxidant activity of peptides derived from egg white proteins by enzymatic hydrolysis. J Food Prot 67, 1939-1944.

201. del Mar Contreras M, Carron R, Jose Montero M, et al. (2009) Novel casein-derived peptides with antihypertensive activity. Int Dairy J 19, 566-573.

202. Hirota T, Ohki K, Kawagishi R, et al. (2007) Casein hydrolysate containing the antihypertensive tripeptides Val-Pro-Pro and Ile-Pro-Pro improves vascular endothelial function independent of blood pressure-lowering effects: contribution of the inhibitory action of angiotensin-converting enzyme. Hypertens Res 30, 489-496.

203. Wong TP, Debnam ES \& Leung PS (2007) Involvement of an enterocyte renin-angiotensin system in the local control of SGLT1-dependent glucose uptake across the rat small intestinal brush border membrane. J Physiol 584, 613-623.

204. Leung PS (2010) Local RAS. In Renin-Angiotensin System: Current Research Progress in the Pancreas: The RAS in the Pancreas, vol. 690, pp. 69-87 [PS Leung, editor]. Dordrecht: Springer.

205. Stevens BR, Fernandez A, Kneer C, et al. (1988) Human intestinal brush-border angiotensin-converting enzymeactivity and its inhibition by antihypertensive Ramipril. Gastroenterology 94, 942-947.

206. Bruneval P, Hinglais N, Alhenc-Gelas F, et al. (1986) Angiotensin I converting enzyme in human intestine and kidney. Ultrastructural immunohistochemical localization. Histochemistry 85, 73-80.

207. Cox HM, Munday KA \& Poat JA (1986) Identification of selective, high-affinity I-125 angiotensin and I-125 bradykinin binding-sites in rat intestinal epithelia. BrJ Pharmacol 87, 201-209.

208. Jin XH, Wang ZQ, Siragy HM, et al. (1998) Regulation of jejunal sodium and water absorption by angiotensin subtype receptors. Am J Physiol 275, R515-R523.

209. Yoshioka M, Erickson RH, Woodley JF, et al. (1987) Role of rat intestinal brush-border membrane angiotensinconverting enzyme in dietary-protein digestion. $\mathrm{Am} \mathrm{J}$ Physiol 253, G781-G786.

210. Dorey PG, King J, Munday KA, et al. (1983) Intestinal fluid absorption in spontaneously hypertensive rats. $J$ Physiol 344, 1-9. 
211. Catalanotto F, Schechter PJ \& Henkin RI (1972) Preference for $\mathrm{NaCl}$ in spontaneously hypertensive rat. Life Sci $1 \mathbf{1 1}$, 557-564.

212. Dahl LK (1961) Possible role of chronic excess salt consumption in pathogenesis of essential hypertension. Am J Cardiol 8, 571-575.

213. Ehlers MRW \& Riordan JF (1989) Angiotensin-converting enzyme: new concepts concerning its biological role. Biochemistry 28, 5311-5318.

214. Amidon GL \& Sadée WE (1999) Membrane Transporters as Drug Targets. Pharmaceutical Biotechnology, vol. 12. New York: Kluwer Academic/Plenum Publishers.

215. Bai JPF \& Amidon GL (1992) Structural specificity of mucosal-cell transport and metabolism of peptide drugs implication for oral peptide drug delivery. Pharm Res 9 , 969-978.

216. Chabance B, Marteau P, Rambaud JC, et al. (1998) Casein peptide release and passage to the blood in humans during digestion of milk or yogurt. Biochimie 80, 155-165.

217. Meisel H \& Schlimme E (1990) Milk proteins: precursors of bioactive peptides. Trends Food Sci Technol 1, 41-43.

218. Meisel H (1997) Biochemical properties of regulatory peptides derived from milk proteins. Biopolymers 43, 119-128.

219. Clare DA, Catignani GL \& Swaisgood HE (2003) Biodefense properties of milk - the role of antimicrobial proteins and peptides. Curr Pharm Des 9, 1239-1255.

220. Korhonen H \& Pihlanto A (2003) Food-derived bioactive peptides - opportunities for designing future foods. Curr Pharm Des 9, 1297-1308.

221. Petrilli P, Picone D, Caporale C, et al. (1984) Does casomorphin have a functional role? FEBS Lett 169, 53-56.

222. Kreil G, Umbach M, Brantl V, et al. (1983) Studies on the enzymatic degradation of $\beta$-casomorphins. Life Sci 33, 137-140.

223. Daniel H \& Hahn A (1990) $\beta$-Casomorphins opioidpeptides derived from milk proteins. Ernährungs-Umschau 37, 95-101.

224. Schmelzer CEH, Schöps R, Reynell L, et al. (2007) Peptic digestion of $\beta$-casein. Time course and fate of possible bioactive peptides. J Chromatogr A 1166, 108-115.

225. Tome D \& Debabbi H (1998) Physiological effects of milk protein components. Int Dairy J 8, 383-392.

226. Pihlanto-Leppala A (2000) Bioactive peptides derived from bovine whey proteins: opioid and ACE-inhibitory peptides. Trends Food Sci Technol 11, 347-356.

227. Gardner MLG (1988) Gastrointestinal absorption of intact proteins. Annu Rev Nutr 8, 329-350.

228. Paganelli R \& Levinsky RJ (1980) Solid-phase radioimmunoassay for detection of circulating food protein antigens in human serum. J Immunol Methods 37, 333-341.

229. Kenrick KG (1970) Immunoglobulins and dietary protein antibodies in childhood coeliac disease. Gut 11, 635-640.

230. Roberton DM, Paganelli R, Dinwiddie R, et al. (1982) Milk antigen absorption in the preterm and term neonate. Arch Dis Child 57, 369-372.

231. Bazin H, Andre C \& Heremans JF (1973) Immunological responses to orally ingested antigens. Ann D Immunol C124, $253-272$

232. Cunningham-Rundles C (1987) Failure of antigen exclusion. In Food Allergy and Intolerance, pp. 223-236 [J Brostoff and CJ Challocombe, editors]. London: Bailliere Tindall.

233. Husby S, Foged N, Høst A, et al. (1987) Passage of dietary antigens into the blood of children with celiac disease. Quantification and size distribution of absorbed antigens. Gut 28, 1062-1072.

234. Jakobsson I, Lindberg T, Lothe L, et al. (1986) Human alphalactalbumin as a marker of macromolecular absorption. Gut 27, 1029-1034.
235. McLean E \& Ash R (1987) The time-course of appearance and net accumulation of horseradish peroxidase (HRP) presented orally to rainbow trout Salmo gairdneri (Richardson). Comp Biochem Physiol A Comp Physiol 88, 507-510.

236. McLean E \& Ash R (1986) The time-course of appearance and net accumulation of horseradish peroxidase (HRP) presented orally to juvenile carp Cyprinus carpio (L.). Comp Biochem Physiol A Comp Physiol 84, 687-690.

237. Walker WA, Abel SN, Wu M, et al. (1976) Intestinal uptake of macromolecules 5. Comparison of in vitro uptake by rat small intestine of antigen-antibody complexes prepared in antibody or antigen excess. J Immunol $\mathbf{1 1 7}$, 1028-1032.

238. Walker WA, Wu M, Isselbacher KJ, et al. (1975) Intestinal uptake of macromolecules 4. Effect of pancreatic duct ligation on breakdown of antigen and antigen-antibody complexes on intestinal surface. Gastroenterology $\mathbf{6 9}$, $1223-1229$.

239. Fiat AM, Miglioresamour D, Jolles P, et al. (1993) Biologicallyactive peptides from milk proteins with emphasis on 2 examples concerning antithrombotic and immunomodulating activities. J Dairy Sci 76, 301-310.

240. Wolf JL, Rubin DH, Finberg R, et al. (1981) Intestinal M-cells: a pathway for entry of reovirus into the host. Science 212, 471-472.

241. Gardner MLG (1984) Intestinal assimilation of intact peptides and proteins from the diet - a neglected field. Biol Rev Camb Philos Soc 59, 289-331.

242. Teschemacher H, Umbach M, Hamel U, et al. (1986) No evidence for the presence of $\beta$-casomorphins in humanplasma after ingestion of cows milk or milk products. J Dairy Res 53, 135-138.

243. Mahe S, Tome D, Dumontier AM, et al. (1989) Absorption of intact morphiceptin by diisopropylfluorophosphate-treated rabbit ileum. Peptides 10, 45-52.

244. Read LC, Lord APD, Brantl V, et al. (1990) Absorption of $\beta$-casomorphins from autoperfused lamb and piglet small intestine. Am J Physiol 259, G443-G452.

245. Tiruppathi C, Miyamoto Y, Ganapathy V, et al. (1993) Genetic evidence for role of DPP-IV in intestinal hydrolysis and assimilation of prolyl peptides. Am J Physiol 265, G81-G89.

246. Gill HS, Doull F, Rutherfurd KJ, et al. (2000) Immunoregulatory peptides in bovine milk. BrJ Nutr 84, S111-S117.

247. Bray GA (2000) Afferent signals regulating food intake. Proc Nutr Soc 59, 373-384.

248. Bakalkin GY, Demuth HU \& Nyberg F (1992) Relationship between primary structure and activity in exorphins and endogenous opioid peptides. FEBS Lett 310, 13-16.

249. Nyberg F, Sanderson K \& Glamsta EL (1997) The hemorphins: a new class of opioid peptides derived from the blood protein hemoglobin. Biopolymers 43, 147-156.

250. Yoshikawa M, Tani F, Ashikaga T, et al. (1986) Purification and characterization of an opioid antagonist from a peptic digest of bovine к-casein. Agric Biol Chem 50, 2951-2954.

251. Lin L, Umahara M, York DA, et al. (1998) $\beta$-Casomorphins stimulate and enterostatin inhibits the intake of dietary fat in rats. Peptides 19, 325-331.

252. Hedner J \& Hedner T (1987) $\beta$-Casomorphins induce apnea and irregular breathing in adult rats and newborn rabbits. Life Sci 41, 2303-2312.

253. Cheng FY, Liu YT, Wan TC, et al. (2008) The development of angiotensin I-converting enzyme inhibitor derived from chicken bone protein. Anim Sci J 79, 122-128.

254. Medhus AW, Sandstad O, Bredesen J, et al. (1999) Delay of gastric emptying by duodenal intubation: sensitive measurement of gastric emptying by the paracetamol absorption test. Aliment Pharmacol Ther 13, 609-620. 
255. Fone DR, Horowitz M, Heddle R, et al. (1991) Comparative effects of duodenal and ileal intubation on gastric emptying and postprandial antral, pyloric, and duodenal motility. Scand J Gastroenterol 26, 16-22.

256. Read NW, Aljanabi MN, Bates TE, et al. (1983) Effect of gastrointestinal intubation on the passage of a solid meal through the stomach and small intestine in humans. Gastroenterology 84, 1568-1572.

257. Hendrix TR \& Bayless TM (1970) Digestion: intestinal secretion. Annu Rev Physiol 32, 139-164.

258. Rao RK, Koldovsky O \& Davis TP (1990) Inhibition of intestinal degradation of somatostatin by rat milk. Am J Physiol 258, G426-G431.

259. Sarfati P \& Morisset J (1988) Inhibition of pancreatic exocrine secretion of intraintestinal somatostatin possible mechanism of action involving the proximal duodenum. Pancreas 3, 616.

260. Konturek SJ, Tasler J, Cieszkowski M, et al. (1981) Studies on the inhibition of pancreatic secretion by luminal somatostatin. Am J Physiol 241, G109-G115.

261. Konturek SJ, Bilski J, Jaworek J, et al. (1988) Comparison of somatostatin and its highly potent hexapeptide and octapeptide analogs on exocrine and endocrine pancreatic secretion. Proc Soc Exp Biol Med 187, 241-249.

262. Jones RE (1977) De-iodination of labeled protein during intestinal transmission in suckling rat. Proc $R$ Soc Lond $B$ Biol Sci 199, 279-290.

263. Moriya H, Moriwaki C, Akimoto S, et al. (1967) Studies on passage of $\alpha$-chymotrypsin across intestine. Chem Pharm Bull (Tokyo) 15, 1662-1668

264. Miller JM, Williard RF \& Polachek AA (1960) An investigation of trypsin I-131 in patients. Exp Med Surg 18 352-370.

265. Kabacoff BL, Avakian S, Wohlman A, et al. (1963) Absorption of chymotrypsin from intestinal tract. Nature 199, 815.

266. Ambrus JL, Lassman HB \& Demarchi JJ (1967) Absorption of exogenous and endogenous proteolytic enzymes. Clin Pharm Ther 8, 362-368.

267. Avakian S (1964) Further studies on absorption of chymotrypsin. Clin Pharm Ther 5, 712-715.

268. Goldberg DM, Campbell R \& Roy AD (1968) Binding of trypsin and chymotrypsin by human intestinal mucosa. Biochim Biophys Acta 167, 613-615.

269. Katayama K \& Fujita T (1972) Studies on biotransformation of elastase 2. Intestinal-absorption of I-131-labeled elastase in-vivo. Biochim Biophys Acta 288, 181-189.

270. Megel H, Beiler M, Ho R, et al. (1964) Detection of trypsinlike activity in plasma of rats after oral administration of trypsin. Arch Biochem Biophys 108, 193-199.

271. Urban E, Zingery AA, Bundrant T, et al. (1982) Permeability of adolescent rat intestine to pancreatic ribonuclease. J Pediatr Gastroenterol Nutr 1, 267-272.

272. Walker WA, Isselbacher KJ \& Bloch KJ (1972) Intestinal uptake of macromolecules: effect of oral immunization. Science 177, 608-610.

273. Warshaw AL, Walker WA \& Isselbacher KJ (1974) Protein uptake by intestine: evidence for absorption of intact macromolecules. Gastroenterology 66, 987-992.

274. Rothman S, Liebow C \& Isenman L (2002) Conservation of digestive enzymes. Physiol Rev 82, 1-18.

275. Goetze H \& Rothman SS (1978) Amylase transport across ileal epithelium in-vitro. Biochim Biophys Acta $\mathbf{5 1 2}$, 214-220.

276. Liebow C \& Rothman SS (1974) Enteropancreatic circulation of an intact digestive enzyme. Fed Proc 33, 409.
277. Levitt MD, Ellis CJ, Murphy SM, et al. (1981) Study of the possible enteropancreatic circulation of pancreatic amylase in the dog. Am J Physiol 241, G54-G58.

278. Rosenblum JL, Raab BK \& Alpers DH (1982) Hepatobiliary and pancreatic clearance of circulating pancreatic amylase. Am J Physiol 243, G21-G27.

279. Levitt MD (1983) Is there an enteropancreatic circulation of digestive enzyme? Am J Physiol 244, G103-G104.

280. Rohr G, Kern H \& Scheele G (1981) Enteropancreatic circulation of digestive enzymes does not exist in the rat. Nature 292, 470-472.

281. Rothman SS \& Grendell JH (1983) Is there an enteropancreatic circulation of digestive enzyme? Am J Physiol 244, G101-G102.

282. Rohr G, Kern H \& Scheele G (1983) Is there an enteropancreatic circulation of digestive enzyme? Am J Physiol 244, G104-G106.

283. Rosenblum JL, Raab BK \& Alpers DH (1983) Is there an enteropancreatic circulation of digestive enzyme? - reply. Am J Physiol 244, G103.

284. Joo K \& Kato Y (2006) Assessment of allergenic activity of a heat-coagulated ovalbumin after in vivo digestion. Biosci Biotechnol Biochem 70, 591-597.

285. Matsubara T, Aoki N, Honjoh T, et al. (2008) Absorption, migration and kinetics in peripheral blood of orally administered ovalbumin in a mouse model. Biosci Biotechnol Biochem 72, 2555-2565.

286. Furrie E, Turner MW \& Strobel S (1995) Partial characterization of a circulating tolerogenic moiety which, after a feed of ovalbumin, suppresses delayed-type hypersensitivity in recipient mice. Immunology 86, 480-486.

287. Tsume Y, Taki Y, Sakane T, et al. (1996) Quantitative evaluation of the gastrointestinal absorption of protein into the blood and lymph circulation. Biol Pharm Bull 19, $1332-1337$.

288. Moreno FJ (2007) Gastrointestinal digestion of food allergens: effect on their allergenicity. Biomed Pharmacother 61, 50-60.

289. Wharton CW (1974) Structure and mechanism of stem bromelain. Evaluation of homogeneity of purified stem bromelain, determination of molecular-weight and kinetic analysis of bromelain-catalyzed hydrolysis of $N$-benzyloxycarbonyl-L-phenylalanyl-L-serine methyl-ester. Biochem $J$ 143, 575-586.

290. Soderholm JD, Peterson KH, Olaison G, et al. (1999) Epithelial permeability to proteins in the noninflamed ileum of Crohn's disease? Gastroenterology 117, 65-72.

291. Chehade M \& Mayer L (2005) Oral tolerance and its relation to food hypersensitivities. J Allergy Clin Immunol 115, 3-12.

292. Frossard CP, Hauser C \& Eigenmann PA (2004) Antigenspecific secretory IgA antibodies in the gut are decreased in a mouse model of food allergy. J Allergy Clin Immunol 114, 377-382.

293. Dannaeus A, Inganas M, Johansson SGO, et al. (1979) Intestinal uptake of ovalbumin in malabsorption and food allergy in relation to serum IgG antibody and orallyadministered sodium cromoglycate. Clin Allergy 9, 263-270.

294. Diesner SC, Knittelfelder R, Krishnamurthy D, et al. (2008) Dose-dependent food allergy induction against ovalbumin under acid suppression: a murine food allergy model. Immunol Lett 121, 45-51.

295. James JM (2004) Food allergy: opportunities and challenges in the clinical practice of allergy and immunology. Clin Rev Allergy Immunol 27, 105-114.

296. Castell JV, Friedrich G, Kuhn CS, et al. (1997) Intestinal absorption of undegraded proteins in men: presence of 
bromelain in plasma after oral intake. Am J Physiol Gastrointest Liver Physiol 273, G139-G146.

297. Walker WA (1987) Pathophysiology of intestinal uptake and absorption of antigens in food allergy. Ann Allergy 59, 7-16.

298. Heyman M (2005) Gut barrier dysfunction in food allergy. Eur J Gastroenterol Hepatol 17, 1279-1285.

299. Gupta S, Jain A, Chakraborty M, et al. (2013) Oral delivery of therapeutic proteins and peptides: a review on recent developments. Drug Deliv 20, 237-246.

300. Rabanel JM, Aoun V, Elkin I, et al. (2012) Drug-loaded nanocarriers: passive targeting and crossing of biological barriers. Curr Med Chem 19, 3070-3102.

301. Kamei N, Nielsen EJB, Khafagy el-S, et al. (2013) Noninvasive insulin delivery: the great potential of cell-penetrating peptides. Ther Del 4, 315-326.

302. Renukuntla J, Vadlapudi AD, Patel A, et al. (2013) Approaches for enhancing oral bioavailability of peptides and proteins. Int J Pharm 447, 75-93.

303. Swaminathan J \& Ehrhardt C (2012) Liposomal delivery of proteins and peptides. Expert Opin Drug Deliv 9, $1489-1503$.

304. Zhang YL, Wei W, Lv PP, et al. (2011) Preparation and evaluation of alginate-chitosan microspheres for oral delivery of insulin. Eur J Pharm Biopharm 77, 11-19.

305. Mukhopadhyay P, Mishra R, Rana D, et al. (2012) Strategies for effective oral insulin delivery with modified chitosan nanoparticles: a review. Prog Polymer Sci 37, $1457-1475$.
306. Olaison G, Sjodahl R \& Tagesson C (1990) Abnormal intestinal permeability in Crohn's-disease - a possible pathogenic factor. Scand J Gastroenterol 25, 321-328.

307. Hollander D (1992) The intestinal permeability barrier. A hypothesis as to its regulation and involvement in Crohn's disease. Scand J Gastroenterol 27, 721-726.

308. Charrier L \& Merlin D (2006) The oligopeptide transporter hPepT1: gateway to the innate immune response. Lab Invest 86, 538-546.

309. Dalmasso G, Nguyen HTT, Charrier-Hisamuddin L, et al. (2010) PepT1 mediates transport of the proinflammatory bacterial tripeptide L-Ala- $\gamma$-D-Glu-meso-DAP in intestinal epithelial cells. Am J Physiol Gastrointest Liver Physiol 299, G687-G696.

310. Terada T, Sawada K, Saito H, et al. (1999) Functional characteristics of basolateral peptide transporter in the human intestinal cell line Caco-2. Am J Physiol 276, G1435-G1441.

311. Terada T, Irie M, Okuda M, et al. (2004) Genetic variant $\operatorname{Arg} 57 \mathrm{His}$ in human $\mathrm{H}^{+}$/peptide cotransporter 2 causes a complete loss of transport function. Biochem Biophys Res Commun 316, 416-420.

312. Shepherd EJ, Lister N, Affleck JA, et al. (2002) Identification of a candidate membrane protein for the basolateral peptide transporter of rat small intestine. Biochem Biophys Res Commun 296, 918-922.

313. Irie M, Terada T, Okuda M, et al. (2004) Efflux properties of basolateral peptide transporter in human intestinal cell line Caco-2. Pflugers Arch 449, 186-194. 